Chapter 7

\title{
The Technical Side of the Hungarian Reconstruction
}

\subsection{The First Year}

The work of Jeremiah Smith, Jr. in Hungary is a tale of a foreigner who worked hard for results that in the beginning seemed hard to reach, and whose manner and positive perseverance gained so many friends in the country for the benefit of which he labored so much. He accepted a challenge in a country that a leading New England daily described as "the country of all Europe least touched by democracy and Western civilization [...] selfish nationalism in impulsive, haughty Hungary now overrun by a defiant Ku Klux Klan of Jewbaiting, Fascisti [sic] terrorist." ${ }^{181}$ Despite such opinions in his home state, from the very moment that he undertook the job, he put all his energies into the work and he believed he was going to succeed. His internationally open-minded personality was fitting for such a task as controlling the Hungarian financial matters, especially that it was under the aegis of the League of Nations, an organization Smith had faith in right from its very conception. Although the time he spent in Hungary was not really long, a little bit over two years, he left an indelible mark on the Hungarian financial and human landscape. His competent but rational individuality made it possible that he and the Hungarian government would work in harmony.

There are really two ways of looking at and assessing Smith's work in Hungary. One is the official side; the other is the private sphere. Thanks to the official duties of Smith, he was required to send a report every month to the League of Nations. In these reports one is able to follow the program of the financial reconstruction of Hungary. Step by step, Smith gave a meticulously detailed survey of the evolution of the state finances and the additional information that concerned daily life and possible outlook. With his reports not only did he cover a given month but also tried to send messages, sometimes well-disguised ones, sometimes hardly so. In sharp contrast, his personal life remained highly elusive. In Hungary he naturally did not change his semi-retired lifestyle; on the contrary, he was even more restrained and tried not to occupy a prominent place in public life. Due to his devotion to work and spending most of his time at his workplace in Budapest or in Geneva, and on account of lack of personal

581 Boston Daily Globe, April 13, 1924. 
correspondence, not much can be learned about the man firsthand. Still, relying on others' memories about him and opinions in the period, a good sketch can be made about the character of the New Englander. It is only logical to start to study his time in Hungary through his reports, because they cover and present most of the Hungarian financial reconstruction program.

Exactly in the same fashion as in the Austrian case, the Commissioner-General for Hungary was required to send monthly reports to the League of Nations concerning the reconstruction plan. Naturally, other information that fell under the scope of finance was possible to include as well. In this respect, Smith had the possibility to study Zimmerman's reports and decided to follow a similar outline. When the two met in early June in Vienna in the shape of a courtesy call from Smith, they discussed besides the two reconstruction programs such questions as well. ${ }^{52} \mathrm{~A}$ characteristic difference between the two men was that Smith sent the press advance copies of his reports for future release-a distinctly American innovation that Zimmerman declined to practice because of lack of confidence in the Austrian press. ${ }^{583}$ Smith's reports alone, however, would give only a one-sided picture of the time he spent in Hungary. With adding ample other information from a score of different sources, the whole picture of the more than two years of financial reconstruction can be studied.

The first more than two months of his job was consumed mostly by two things. One was the raising of the international loan for Hungary, discussed in detail in the previous chapter. The other was to ensure and watch over the transition phase before the loan was launched. After his arrival on May $1^{\text {st }}$, Smith immediately flung himself into the thick of things in Budapest. The very same day he visited the members of the Cabinet and heads of the diplomatic missions, and started work on Monday, May $5^{\text {th }} .{ }^{584}$ He also met with the representatives of the press the first week. He emphasized that he thought the main job of the newspapers lay "in reassuring the Hungarian public opinion, whose faith and trust were in great need." 585 He naturally met with Bethlen but was quick to reiterate his independent and unbiased status when the leaders of the Kossuth Party made a courtesy call at his office. ${ }^{586} \mathrm{He}$ believed that he must remain above local politics if he wanted to achieve positive results. His popularity, which was tangible from the first day, was mounting each week. This was largely attributed to his modest and sympathetic personality and behavior. His office was in the building of the Finance Ministry, with a desk originally used by Lajos Kossuth.

582 The New York Times, June 4, 1924; Magyarország, June 3, 1924, XXXI/107.

583 The New York Times, September 2, 1926.

584 Balfour to MacDonald, May 9, 1924, C7751/21/21, 9902, FO371, TNA; Magyarország, May 6, 7, 1924, XXXI/84, 85.

585 Magyarország, May 10, 1924, XXXI/88; Budapesti Hírlap, May 10, 1924, XLIV/88.

586 Pesti Napló, June 6, 1924, 75/110. 
His quarters were very modest. He refused accommodations in the Royal Palace or a luxury suite in Hotel Hungaria, and rather moved to the top floor of the hotel in a single bedroom. ${ }^{587}$ With such steps, the Commissioner-General managed to make a very good first impression in Hungary.

In early June, duty called Smith to Geneva, Switzerland, headquarters of the League of Nations. It was the time of the summer session and Smith was to present in person his first report of the reconstruction. Obviously, close attention was following this second League-initiative and many officials and observers were keen on hearing the American Commissioner-General's first impressions. He divided his reports into small parts touching upon the subjects of inflation, assigned revenues, measures of reform, financial, and statistical tables in the appendix, but these were often changed later due to the pending issues. On June $14^{\text {th }}$, Jeremiah Smith, Jr. appeared before the League Council for the first time in his official capacity and explained his first report.

In this report covering the month of May, the American described the major events of the first month concerning the reconstruction program. After outlining the subscription of the National Bank's shares, he stated that compared to the Austrian subscription the picture was satisfactory. ${ }^{588}$ Since the flotation of the international loan was still weeks away, the interim time had to be bridged financially. For this reason, the Hungarian government secured in April a 20-million Swiss franc loan, and a domestic forced loan to cover the deficits. In May, the Vienna stock exchange speculation caused some anxiety, and "the natural consequences in a country which since the war has become accustomed to feel disillusioned was that the difficulties of the moment overshadowed everything else in the public estimation, and faith in the prospects of the reconstruction programme could only be won at the price of concrete evidence which it was not possible to furnish immediately." This unfavorable situation was furthered by a general increase in prices, and it caused an almost $30 \%$ drop in the currency. Although Smith was satisfied that most prohibitions on exports (wheat, rye, barley, hay, and meat) had been abolished since the League delegation's visit in March, he criticized the pending tariff bill as one that does not follow the suggestion of the Financial Committee. In conclusion, despite that "the mentality of the country was not altogether favourable at the outset," he asserted that "generally speaking, the conditions appear fundamentally sound

587 Boston Daily Globe, May 22, 1924.

588 Smith's First Report, LNJ, $5^{\text {th }}$ Year, No. 7, July 1924, 974-981. Subsequently, Smith's reports will be given with the LNJ as source in the first footnote, thereafter they will be referred to only according to their number. Smith's reports can also be found in BoE, OV9/434 and /436. The whole First Report can be found in the Appendix. A short summary of Smith's reports usually appeared in the Wall Street Journal, The New York Times, and The Times. 
[...] There is no reason apparent why the execution of the Reconstruction plan should not produce the expected results." ${ }^{\prime 89}$ This sentence was what Goode later described as "a good deal of courage." ${ }^{\text {" } 90}$ Smith's optimism partly stemmed from the fact that he already in May established that the revenues from the assigned assets would exceed the League estimates. ${ }^{591}$ Also, he was an optimist by nature.

Still it cannot be said that Smith was satisfied with everything. One thing that bothered him was the late time that budget plans, actual budgets, and closed accounts reached him. He laid stress on it that "preliminary budgets should not be furnished at the last possible moment but should be submitted to the Commissioner-General a sufficient length of time in advance to permit careful examination of their details." He was of the opinion that in other fashion they would lose their value. He also requested "that accurate statements of debts concentrated and remaining unpaid should be furnished monthly, and the success of the plan depends in no small degree upon establishing a practice which will insure these results." But it was not only the lack of data that created problems; he also had to cope with a strange environment: "So much time has been spent during the first month in organization of the control and in becoming acquainted generally with the economic, financial and administrative conditions that it has not been possible to prepare statistical tables for the first report." 592 In his verbal summary in Geneva, Smith praised both the Financial Committee and the Hungarian government, the first for the preparation of the plan, the latter for its cooperation. ${ }^{593}$ With this successful and sanguine performance both the League and Hungary could rest assured that the process of rehabilitation had commenced satisfactorily.

In Geneva decision was also made about the Commission-General's expenses. As Smith's detailed calculation showed, he and his staff would need $\$ 4,642$ a month. ${ }^{594}$ This covered besides Smith's salary the salaries of Tyler, Siepmann, Charron, and Licen, the work of the clerical staff, and expenses relating to translations and traveling. ${ }^{595}$ At the meeting in Geneva, the Council authorized Smith's total expenses at $\$ 5,000$ a month. ${ }^{596}$ A Hungarian historian, in all likelihood driven by ideological consideration, wrote, in addition to Smith's being sent by J. P. Morgan personally, that

589 Smith's First Report.

590 The Times. May 23, 1925.

591 Balfour to MacDonald, May 16, 1924, C8073/37/21, 9908, FO371, TNA.

592 Smith's First Report.

593 LNJ, $5^{\text {th }}$ Year, No. 7, July 1924, 910.

594 LNA, C. 267, 1924. II.

595 9/VII/6/183. The second Budapest negotiation in March 1924 and its antecedents.

The first report of the Commission-General in Geneva, K 275, Kállay Papers, HNA.

596 LNJ, $5^{\text {th }}$ Year, No. 7, July 1924, 911. 
The incredible sum which ]. Smith [...] pocketed each month as his salary expresses the unscrupulous exploitation of the country more clearly than anything else. J. Smith was given 5,000 dollars monthly as honorarium and office expenses [...] which sum was almost three times the pay of the head of the Hungarian State, Regent Horthy [...] at this time. ${ }^{597}$

Naturally, the 5,000 dollars were provided for Smith and the whole staff, not for Smith alone. The staff included three typist secretaries and a male messenger clerk as well, and there were expenses related to translations and traveling. ${ }^{598}$ This was a typical manifestation of how post World War II Hungarian historiography changed or tilted certain facts in the interwar period and presented them in a falsified way.

In light of this distorted interpretation and later events, it is important to quote the note attached to the above decision: "The Commissioner-General does not intend to draw upon the amount provided for his salary for more than his actual living expenses at Budapest and travelling expenses for the purpose of his work. As far as he can judge at present, his expenses may amount to some $\$ 8,000$ yearly." 599 So, Jeremiah Smith, Jr. already in the beginning decided not to spend or accept any extra money save for his actual living expenses and this move basically meant that he forwent his salary. This noble act was followed by exasperation on Smith's part when the question of expenses was brought to public. ${ }^{600}$ The root of his anger was that the resolution was read at a private meeting in order not to get out to the press, but it still leaked out. In the given situation he wanted to avoid even the possibility of the Hungarian public discussing how much money the foreign controllers received when the population had to endure extra burdens. He was quick to reassure to the Hungarian press that the sum was a maximum and he was not going to spend a cent more than necessary. ${ }^{601}$ He naturally did not want his precarious situation to be attacked on the ground of such banal things. He wanted to evoke confidence toward his own self and the work of the reconstruction.

597 Magos, "The Role of the British and American Imperialists," 202.

598 9/VII/6/183. The second Budapest negotiation in March 1924 and its antecedents. The first report of the Commission-General in Geneva, K 275, Kállay Papers, HNA.

599 E. I. Expenses of the Office of the Commissioner General, C. 113, Financial Reconstruction of Hungary, LNA; 9/VII/6/183. The second Budapest negotiation in March 1924 and its antecedents. The first report of the Commission-General in Geneva, K 275, Kállay Papers, HNA.

600 Smith to Salter, June 16, 1924, Dossier concerning the departure of the Commissioner General from Budapest. Doc. No. 36545, Registry Files 300, R. 300, LNA.

601 Budapesti Hírlap, June 17, 1924, XLIV/118; Magyarország, June 17, 1924, XXXI/118. 
The second report of Smith covered the month of June. Due to some lapse between the period covered in these reports and the necessary time needed to work on the data, it came out on July $22^{\text {nd }}$. Of the various issues he touched upon three deserves mentioning. One was the state of finances. The revenues from customs and tobacco had increased immensely since May, but the estimated deficit for July was almost 5 million gold crowns more (\$1 million) than in the Reconstruction Program. He quickly added that this was no basis for worry, because July was a weak month in terms of revenues, under the monthly average, plus tax collection of direct taxes fell on the months of February, May, August, and November, thus the weak results. The overall good news was that it was clear that by the end of June there would be already a surplus compared to what the League had estimated. Smith, however, was quick to add that it did not mean the possibility of any changes in budget limits. As he put it, "in approving the []uly] budget, I have called the attention of the Government to the fact that the monthly deficits during the balance of the calendar year must be reduced below the monthly average, in order that the total deficit for the six-months period shall not exceed the deficit for that period fixed in the reconstruction budget, and that I shall be governed by this consideration in making future releases." ${ }^{102}$

Another point was the problem of the state employees. It was a rather difficult one that was to haunt the program all throughout, therefore giving credence to Smith's prediction that "the question of the State employees is a difficult one and likely to remain so." The disproportionally high number of state officials meant a very big financial burden on the budget; roughly $60 \%$ of the annual expenditure was for pay for personnel and pensions. In addition, the government granted an increase in their pay from July $1^{\text {st }}$ instead of October $1^{\text {st }}$, which nonetheless was acceptable in the light of the fact that their salary was very low and hardly enough to make ends meet. The third interesting point was Smith's practicality that he advanced money for the government when the proceeds of the loan were not on hand yet in June. It would have made little sense to play rigid and endanger the smooth run of the program over technical points. In conclusion, Smith professed careful optimism when he wrote, "The successful issue of the loan cannot of itself effect miracles; the execution of the plan is the only way of establishing a firm foundation for the future; this requires time and will require sacrifices in addition to those already made, but I have every confidence they will be made when necessary and that the Hungarian people will take full advantage of this opportunity." ${ }^{603}$

This positive attitude and practical approach shown by the CommissionerGeneral found resonance in Hungary. Bethlen praised Smith's decency and

602 Smith's Second Report, LNJ, $5^{\text {th }}$ Year, No. 9, September 1924, 1228-38.

603 lbid. 
knowledge and said that he had won the love and respect of not only those who had official contact with him but the whole population. ${ }^{604}$ Smith also had a very good opinion about his relation with the government and he described their discussions about budget issues "amicable."605 These discussions at present mainly focused on the July budget, which the Commissioner took issue with because it stepped over the limits of the budget Law. Finally, the two sides found a middle ground and Smith accepted the reasoning of the government about the installments of the forced loan that was not included in the reconstruction budget, and he approved the July budget. ${ }^{606}$ To take further steps in the smooth cooperation of both sides, Smith was willing to take part in rare public events. One was the $4^{\text {th }}$ of July commemoration in the City Park at the statue of George Washington organized by the Hungarian-American Society. Both Smith and Brentano appeared and all the speakers praised Smith and he got a cheer from the people present. ${ }^{607}$ All these signs showed that the American controller had been accepted and so far his work had been successful. Naturally, with the successful flotation of the loan in the first two weeks of July, which made it seem assured that the necessary money would be on hand to carry out the program, his status became even more respected in Hungary.

July was a very important month not only because of the international loan. Most significantly, an early agreement was made about the official multiplier. This was the number stating the ratio between a gold crown and paper crowns. It was fixed at 17,600 in July, though the real value should have been 16,000. Despite the fact that still in July it was reduced to 17,000 , Smith was not satisfied with this state of affairs, and in the future wanted to see it reduced, because in this form it caused a net loss. The estimated August budget deficit was again largely in excess of the planned deficit, so Smith asked the government to reduce it by 2 million gold crowns. In the wake of this problem, agreement was reached that the departments would submit their budget plans to the Finance Ministry till the $15^{\text {th }}$ of each month, while the Finance Ministry would submit the whole monthly budget plan for the state to Smith till the $20^{\text {th }}$. This way the parties could avoid having such arguments in the future. ${ }^{608}$

604 Budapesti Hírlap, July 2, 1924, XLIV/131.

605 Smith to Salter, June 28, 1924, Miscellaneous correspondence. Doc. No. 35939, Registry Files, R. 413, LNA.

606 Smith to Korányi, July 10, 1924, C.III. (7) Correspondence - Hungarian Ministers, 1924, C. 111, Financial Reconstruction of Hungary, LNA.

607 Brentano to Hughes, August 16, 1924, 864.00/586, Roll 6, M. 708, NARA; Budapesti Hírlap, July 7, 1924, XLIV/135.

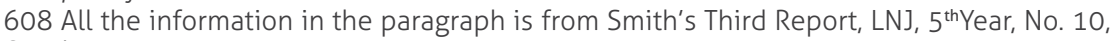
October 1924, 1447-58. 
The administrative reforms had begun as well. The total number of officials dismissed on June $30^{\text {th }}$ was $6,991 .^{609}$ In connection with this, the Commissionergeneral made the following observation:

Present Hungary, which has approximately one-third of the geographical area and 40 per cent of the population of the country as it existed before the War, has about 60 per cent of the pre-war number of State employees and that the classified personnel of the Civil Administrations (excluding the State undertakings) has actually at the present time more functionnaires de classe than there were in 1913. This is due partly to the War. Many Hungarian civil servants, who were employed in those parts of Hungary annexed to other countries by the Treaty of Trianon, returned to Hungary. They had claims upon the Hungarian Government for retention in the Civil Service which could not be ignored, and naturally resulted in a very large establishment which, in turn, results in an underpaid Civil Service, the total expense of which is nevertheless a heavy drain on the Government Treasury. Other changes were made soon after the end of the War which contributed to the increase rather than to the decrease of the staff of the Civil Administrations. The Reconstruction plan makes no attempt to deal with this situation other than providing for the discharge of 15,000 employees [...] It is apparent that, so long as a large proportion of the State revenues must be spent on the payment of its employees, the amount available for other purposes will be correspondingly limited.

Still, it was the pensioners who suffered the greatest cutbacks in the new fiscal policy with a decrease of $40 \%$ as of July $1,1924 .{ }^{610}$

As far as state finance went, however, things looked surprisingly good. The assigned revenues kept coming in neatly. The highest of them was that of tobacco, which the British minister attributed to the new regulation that forbade shops selling tobacco to close their doors during "an indefinitely long luncheon hour!"611 In Smith's view the most important thing was the step toward "the establishment of confidence, both internally and externally, in the permanence of the conditions within Hungary created by the operation of the Reconstruction plan [and] a normal and healthy market has been re-established in Hungarian crowns." ${ }^{12}$ But confidence worked toward his direction too. Smith seemed, in the American minister's words, "to retain the entire confidence of Hungary and

$609 \mathrm{lbid}$.

610 Romsics, István Bethlen, 238.

611 Barclay to MacDonald, July 19, 1924, 11764/21/21, 9903, FO371, TNA.

612 Smith's Third Report. 
to maintain the popularity with which he was first received."613 In July, none other than Boyden came to call on Smith to get firsthand information about the execution of the program in Hungary. ${ }^{614}$ Naturally, Smith was happy to see a compatriot who was also a good friend. Such a visit meant a high point in his otherwise hermit-like lifestyle. As one paper wrote, he started at his workplace at nine and never left before six, but often stayed late and carried home with him big folders to study. ${ }^{615}$ He was really in the thick of things concerning his duty.

On August $1^{\text {st }}$, Smith had been in Hungary for three months and he reiterated his optimism concerning the reconstruction work. ${ }^{616}$ He had really won the confidence of the Hungarians and was not seen at all as "the financial czar of Hungary," a label that foreign newspapers tagged him with. ${ }^{617}$ The most momentous event of the month was James Speyer's visit to Budapest. ${ }^{618}$ The American banker, whose Company led the way in issuing the American tranche of the Hungarian reconstruction loan, came to the Hungarian capital to conclude further business. Speyer, who was provided with Smith's monthly reports directly by the Commissioner-General, wanted to achieve his business objective that was frustrated in June. His stay was marked by generous Hungarian hospitality, led by the government. A dinner was given in his honor in the prestigious Gerbaud by József Vass, deputy prime minister, where all the foreign notables and a Hungarian who's who were invited. ${ }^{619}$ The next day it was finance minister Frigyes Korányi, who gave a smaller dinner for Speyer and his team. ${ }^{620}$ The lavish reception was the result of the fact that Speyer $\&$ Co. did manage to take over $\$ 1.5$ million from the Hungarian tranche, $80 \%$ of the domestically raised total amount, increasing the American participation to \$9 million, while at the same time reducing the Hungarian participation to $\$ 850,000 . .^{621}$ The real cause behind that move was that the American issue stood at a premium of $2 \frac{1 / 2}{2}$ in New York, and Speyer hoped to include the Hungarian part under the same condition. ${ }^{622}$

613 Brentano to Hughes, August 16, 1924, 864.00/586, Roll 6, M. 708, NARA.

614 Boyden to Smith, July 12, 1924, T.II., Incoming Telegrams, July-August, 1924, C. 120, Financial Reconstruction of Hungary, LNA.

615 Pesti Hírlap, July 13, 1924, XLVI/140.

616 Budapesti Hírlap, August 1, 1924, XLIV/156

617 The New York Times, August 3, 1924.

618 Speyer arrived together with K. W. Krech, President of the Equitable Trust Company, the house Speyer $\&$ Co. launched the Hungarian tranche together, but in all measures it was Speyer's personality that mattered.

619 Daily News, Daily Reports (1920-1944), August 13, 1924, K. 428. a, HNA.

620 Daily News, Daily Reports (1920-1944), August 14, 1924, K. 428. a, HNA.

621 Smith to ter Meulen, August 21, 1924, L.V. c-1, Jun 24-Jun 30, 1924, C. 114, Financial Reconstruction of Hungary, LNA; Korányi to Smith, August 22, 1924, and ter Meulen to Smith, August 23, 1924, C.III. (7) Correspondence - Hun Minister, and C.III. (11) Correspondence Mr. C. E. ter Meulen, C. 111, Financial Reconstruction of Hungary, LNA.

622 Barclay to MacDonald, August 15, 1924, C13283/37/21, 9909, F0371, TNA. 
The transaction was largely a result of the successful negotiations between Fülöp Weiss, President of the Hungarian Commercial Bank of Pest, the agents of Speyer, and Speyer \& Co. ${ }^{623}$ Smith approved of the deal, but asked official approval, which the Trustees duly gave. ${ }^{624}$ The contract was signed in Geneva on September $3^{\text {rd }}$, and it was amended compared to the earlier contract in a fashion favorable to Speyer \& Co. ${ }^{625}$ The business aim that Speyer \& Co. should enjoy exclusive rights in case of future Hungarian loans in the United States now was achieved. Hungarian Finance Minister Korányi signed the relevant contract with the Americans:

As you have declared your willingness to purchase out of the Hungarian tranche of the State Loan of the Kingdom of Hungary 1924 obligations to the amount of $1 \frac{1 / 2}{2}$ million dollar of nominal value, I undertake on behalf of the Hungarian Government, according to your wish the engagement that the Hungarian Government will not make arrangements with any American financial concern as to the issue or purchase of a direct or indirect Hungarian Government loan or a similar financial transaction in New-York U.S.A. for which the negotiations would commence after the conclusion of the purchase of the additional \$ 1.500 .000 bonds, without inviting the offer of Messrs. Speyer $\&$ Co. and that in such future transactions the Hungarian Government will, in the case of equal conditions, give preference at all times to the offer of Messrs. Speyer \& Co. ${ }^{626}$

This was also a sure sign that the two parties would work together in the future again, which was the undisguised aim of the American banking house. On the other hand, the Hungarian government was equally happy to have an American banking house to count on.

Smith began his fourth report with the following statement: "The fact that I have little to report with regard to purely financial conditions may be taken as a satisfactory symptom." The actual deficits for July and August showed a much favorable picture than estimated and the revenues, for the summer months covered comfortably the annual service of the loan, which were 31 million gold crowns. The bigger than estimated revenues were welcomed because the first

623 "Report on the Work of the Savings Banks and Banks in 1924," 16. 5/1923-1928 B/3, K 468, Bethlen Papers, HNA. Later on this Hungarian Bank represented the interests of Speyer \& Co. in Hungary.

624 Smith to ter Meulen, August 21, 1924, and Smith to Speyer, August 22, 1924, L. V. c-1, June 24-30, 1924, C. 114, Financial Reconstruction of Hungary, LNA.

625 The text of the new contract is in 9/VIII/5/68-73, K 275, Kállay Papers, HNA.

626 Hungarian Royal Minister of Finance to Speyer \& Co., September 3, 1924, 332 /116, K 269, Finance Ministry, General Papers, HNA. 
quarter of the financial year was always the worst in terms of deficit and the data provided by the Treasury showed that the next quarter would be even better. Retail prices, though still high, had started to fall, and there were signs that the country had adjusted itself to the new conditions. In addition to the increasing revenues, speculation on the stock exchange had largely ceased, and deposits in the banks began to show an increase. Naturally, this was only one side of the equation. Smith put in perspective that only long-term capital could alleviate the problem of a country that was notoriously poor in capital. "But the genuine shortage of capital which exists in Hungary will not be relieved by offers of money for a few months at a time. Such relief can come only if foreign capital seeks out the opportunities which undoubtedly exist for relatively long-term investment in productive Hungarian enterprises, or if sufficient savings can be accumulated gradually in Hungary for re-investment in the enterprises of the country". ${ }^{627}$

As a closing act to the summer, on August $30^{\text {th }}$ Smith appeared again in front of the Council in Geneva to give a summary of his work so far. He gave a succinct but accurate picture of the past four months and how the reconstruction had advanced since his arrival. He repeated the satisfactory amount of the revenues and further indicated that Hungary had become a healthily functioning country by giving the example of the stock exchange, whose volume had increased by a factor of 90 since the opening of the National Bank back in June. ${ }^{628}$ Smith praised the League and the Financial Committee for "a striking illustration of international cooperation," and he also had warm words for the "faithful cooperation of the Hungarian Government and people." 629 He declared that the first stage had been passed, the second stage could begin, and he was optimistic that the work would be successful. ${ }^{630}$ As he said, the main task now would be that of reducing the budget expenditure to the level fixed in the reconstruction program and to conclude commercial treaties. Korányi also spoke and praised the League and Smith, while the League congratulated the Hungarian government and Smith. ${ }^{631}$ The meeting at Geneva also decided about the three trustees, who were Giuseppe Bianchini, Henry Strakosch, and Carel Eliza ter Meulen. ${ }^{632}$ When the American returned to Budapest in mid-September, he was pleased to declare in an interview that at Geneva the question of the Hungarian reconstruction got

627 All the information in the paragraph is from Smith's Fourth Report, LNJ, $5^{\text {th }}$ Year, No. 11, November 1924, 1741-48.

628 8/35, K 78, Népszövetségi Kiadványgyújtemény [Collection of League of Nations Publications], HNA.

629 Ibid., 36-37.

630 lbid., 37.

631 LNJ, 5th Year, No. 10, October 1924, 1289-1291.

632 Ter Meulen represented Hope \& Co., Amsterdam, Bianchini was President of the United Bank of Italy, while Strakosch was member of the Financial Committee of the League of Nations. 
the biggest attention, aside from that of disarmament, and he received positive feedback from everywhere. ${ }^{633}$

In his report for September, the Commission-General could once again provide the news the officials hoped to hear in Geneva: revenues pledged as security kept growing; prohibitions on export were almost totally removed and requirements of import licenses were largely abolished, though there was the new tariff law; the volume of total trade was increasing significantly; wholesale prices had diminished by $2.3 \%$ in August for the first time; the number of unemployed went down since July (from 31,134 to 20,026) among the members of the Union of Socialist Workers. Naturally, Smith did not allow the government or the Hungarian people to believe that the worst was over. "In order to avoid misapprehension, it should be realised that the gain in actual over estimated receipts, and the consequent reduction of the estimated deficit for these three months [July, August, September], does not mean that the Government is in a position to spend more money than the amounts fixed in the reconstruction programme." Besides, on September $17^{\text {th }}$ the National Bank raised the discount rate from 10 to $12 \frac{1}{2} \%$, but Smith quickly concluded that it was part of a normal seasonal fluctuation. ${ }^{634}$ In his home country, Hungary also got in the focus a little bit because of Smith's favorable report. ${ }^{635}$

Not everyone involved in the execution of the reform program was automatically optimistic about the results. Harry Siepmann, the foreign adviser at the National Bank, was one. In his frequent letters to Norman, he often gave voice to criticism if he thought it justified. In a letter written on the same day as the raise of the discount rate, Siepmann formulated his opinion in a striking fashion when he said there was "a fundamental mistake in the reconstruction plan." ${ }^{636}$ The basis for this statement was that only putting the state finances in order would be less than what was needed. According to Siepmann, Popovics agreed with the Briton, and asserted that in a country where foreign capital had always been and would be a primary asset, automatic reconstruction would not be achieved just by making budget deficit disappear. ${ }^{637}$ This small episode is a good example how difficult the situation was. The numbers told only one side of the story, but future prospects might not depend on present figures alone. Still, this observation, however true it might have been, did not render those good numbers valueless. On the contrary, what Hungary had been able to produce in the short time span since late spring was more than what could have been expected. Maybe a slight indication that foreign trust had returned

633 Budapesti Hírlap, September 16, 1924, XLIV/192.

634 All the information in the paragraph is from Smith's Fifth Report, LNJ, $5^{\text {th }}$ Year, No. 11, November 1924, 1749-58.

635 28/1924 I-5. Washington/788, K 66, Press and Cultural Department, HNA.

636 Siepmann to Norman, September 17, 1924, OV 33/37, BoE.

637 lbid. 
toward Hungary was that Charles E. Mitchell and Paul Grosjean, President and VicePresident of the National City Bank of New York, came to Budapest to study local conditions and the possibility of investing in form of a loan. ${ }^{638}$

The next month again produced a favorable report from Smith. Thanks to the high customs revenues, assigned revenues were the largest so far. For the first time, the estimated budget for November showed a small surplus and wholesale price index showed a slight decrease again. Despite the surplus of 2 million gold crowns in October, Smith was careful because state expenditure was still higher than estimated: "The conclusion should not be drawn that the State is in a position to incur additional expenditures." Smith dealt with the Hungarian State Railways in detail, which was the most important state enterprise. The obvious reason for this was that the surpluses or deficits created by the various state enterprises had a significant bearing on the state budget. From a financial point of view, everything seemed all right with the State Railways; the preliminary numbers even showed a little surplus. But there was more to the numbers than first met the eye, and it also caught Smith's attention. The problem was that $16.7 \%$ of the operating expenses was eaten up by pensions, while in the pre-war years this figure was only $3-4 \%$. In addition, compared to the numbers of active employees, in 1913 pensioners represented 16\%, while in 1924 this was 90\%, and further increase was expected. The number of people employed at this time was around 60,000. The expenditure on coal showed again a curios picture. The Railways now spent on coal $94 \%$ of what it had before the war, although the railway system had only $40 \%$ of the number of kilometers, and rise in coal prices could be only a partial explanation. According to Smith's observations, small cuts should be practiced in basically every field in the enterprise over a longer period, which must not affect wages, because they were already very low. ${ }^{639}$

The government continued to use the multiplier of 17,000 paper crowns to one gold crown, which was $10 \%$ above the real value. As a result of this, state officials were overpaid with $10 \%$, which meant deficit for the state, but agreement was reached with the Financial Committee that till the end of the calendar year this should be upheld. This was doubtless a fundamental question, but common sense dictated that it was well worth losing some money on these inflated payrolls in order to keep the many officials financially afloat, especially when all the figures indicated that deficit had disappeared and soon surplus would be realized. Still, Smith found it prudent to attach his mild warning: "The conclusion should not be drawn that the State is in a position to incur additional expenditures." ${ }^{640}$

638 Curtis to Hughes, October 7, 1924, 864.00/590, Roll 7, M. 708, NARA. 639 All the information in the paragraph is from Smith's Sixth Report, LNJ, $5^{\text {th }}$ Year, No. 12, December 1924, 1835-45.

$640 \mathrm{lbid}$. 
Despite the good numbers, the month of October witnessed the first problems of the reconstruction. There was a continuation of general business depression and economic stagnation, with many bankruptcies. In the first half of the month there was a panic on the stock exchange with 15-25\% drop in quotations, but the government solved the situation providing 100 billion paper crowns. ${ }^{641} \mathrm{Smith}$ himself had his moments of uncertainty because of the situation. Aside from the budget issue and despite the good overall picture, he had the sensation of "wandering about in a pretty thick fog." 642 One of his complaints was that there were too many banks in the country and he was sure that many of them ought to be simply closed. ${ }^{643}$ The leading banks, on the other hand, thrived. There is statistical data only for the fourteen most important banks at that time, but these numbers showed a steady increase in savings. Smith included this table in his reports and the numbers reflected a trusting public inasmuch the amount of savings kept growing. ${ }^{644}$

In November revenues once more reached the peak so far, largely thanks to the customs receipts. Smith did not necessarily think that high customs receipts were a good thing. As he noted, it meant that those who brought the goods into the country paying high customs duty would want to sell them at a high price as well, thus the price index would remain high. If the prices did fall, however, it would mean that the trader, who had paid a large customs duty, had to suffer a substantial loss-neither scenario was very encouraging. The Hungarian Treasury wanted to spend the surplus on hand immediately, but Smith resisted such ideas and wanted a longer period to pass before he authorized any such action. The Hungarian currency had gained strength thanks to the pound becoming stronger against the dollar. ${ }^{645}$ This was thanks to the movement to bring back the pound to gold parity, even if about $10 \%$ overrated. In the scheme the main actors were Strong and Norman: their cooperation made it to a great degree possible for the pound to reach the magic number in the spring of 1925.646 For the first time, there was a slight surplus in foreign trade, and compared to 1923 the increase in volume was $63.8 \%$. Still, as Smith noted, it was "substantially $20 \%$ of the foreign trade of pre-war Hungary for the same period of time, and about $50 \%$ of the estimated normal volume of trade of present Hungary." ${ }^{1647}$ Somewhat shocking

641 Curtis to Hughes, November 8, 1924, 864.00/597, Roll 7, M. 708, NARA.

642 Smith to Strakosch, October 20, 1924, OV9/434, BoE.

$643 \mathrm{lbid}$.

644 Smith's Seventh Report, LNJ, 6 ${ }^{\text {th }}$ Year, No. 3, March 1925, 388-96.

645 Smith's Seventh Report.

646 In more detail about this subject, see Clay, Lord Norman, 134-171; Chandler, Benjamin Strong, 291-331; Clarke, Central Bank Cooperation, 71-104; and Ahamed, Lords of Finance, $224-40$

647 Smith's Seventh Report. 
was the revelation in the November report that the retail price of many textile articles was 50-100\% more than in the United States, Great Britain, and France, a phenomenon with no clear explanation. ${ }^{648}$

The month also produced some strange news. A certain Feldman of Belgium appeared on the scene and was trying to act as a coordinator of the Hungarian government in raising a loan for the Hungarian Railways. Norman and Niemeyer were upset about this non-official route and Smith promptly let them know that no one had ever heard about Feldman in Hungary. ${ }^{649}$ Norman's irritation stemmed from the fact that similar attempts had in fact been made by Hungary's neighbors. He warned the Hungarians not to fall in the same trap as the Austrians and Czechs, who had become known to "make a habit of injuring their credit by semi-official loanmongering." 650 There were genuine channels working as well. Speyer asked Smith about the chances of another government loan for Hungary. Smith replied that neither he, probably nor the Reparations Commission would agree to such a plan. ${ }^{651}$

In Britain, where interest obviously was big toward both the Austrian and Hungarian reconstructions, an article in The Times gave a mixed picture about the results in Hungary. Despite admitting that businessmen were "looking confidently to the future," the author did not mince his words when he described the daily situation: "Business is dead and is bound to become deader still [...] Many shops are shut, and the centre of the city after dark is like the grave. Now and for some time to come there will be little money to spend." ${ }^{652}$ As for Smith, the article went on to say: "He is credited with extreme broad-mindedness and impartiality, and his personality is surrounded by a sort of nimbus of dollars." 653 Both sides of this analysis were fair. On the one hand, the expected depression had set in, however promising the fiscal

\footnotetext{
$648 \mathrm{lbid}$.

649 Smith to Norman and Niemeyer, November 12, 1294, and Norman to Smith, November 18, 1924, S. III. a. 1, C. 119, Financial Reconstruction of Hungary, LNA.

650 Norman to Smith, November 4, 1924, Ibid.

651 Smith to Speyer, November 19, 1924, Ibid. For some time, therefore, Speyer \& Co. had to wait for another possibility to invest in the Hungarian market. It does not mean that the company was not active elsewhere. It was particularly true in Germany, where despite the fact that Speyer \& Co. was prevented from taking part in issuing the Dawes loan due to J. P. Morgan, they made up for it in the following years. As a matter of fact, the Company issued altogether $\$ 53.8$ million, mainly in city and railway loans. Speyer \& Co. issued $\$ 10$ million for the German Railway Co. in November 1924, \$15 million for the City of Berlin in July $1925, \$ 3,750,000$ for the City of Dresden and $\$ 2,800,000$ for the City of Frankfort, both in November 1925, $\$ 6,500,000$ for the Hamburg-American Line in December 1925, $\$ 3,750,000$ for the City of Leipzig in March 1926, and $\$ 12,000,000$ for the Berlin Electric Elevated and Underground Railways Co. in November 1926. Robert R. Kuczynski, American Loans to Germany (New York: The Macmillan Company, 1927), 20, 44, 46, 48, 51.
}

652 The Times, November 24, 1924.

653 lbid. 
numbers may have been; as far as Smith went, he was really liked for his modest and unbiased behavior.

December meant the end of the first half of the 1924/25 fiscal year, so the results so far were important and indicative of future prospects. Smith's monthly report for this month emphasized the good news that payments from the loan for monthly deficits and providing working capital had to be made only in the first four months (July-October) and there was a surplus of 2.1 million gold crowns $(\$ 420,000)$ after the first six months. Receipts for pledged revenues were again higher than in the previous month. Although expenditures were $10 \%$ higher than fixed in the reconstruction program and also higher than provided at the end of the reconstruction period, revenues were about $40 \%$ higher than estimated. Deposits in the banks and the number of the unemployed kept growing. The multiplier used for converting gold into paper money had been reduced from 17,000 to its true ratio of 15,100 , which was another indication of healthier circumstances. This fact was important because importers, on account of the too high multiplier, had to pay an extra tax in essence, which now with the real value of the multiplier had disappeared. Despite all the favorable results, Smith still warned against "premature conclusions," because he was of the opinion that the pledged revenues would not be able to produce as much in the second half of the financial year. As he noted, in this case any extra expenditure on the part of the government would either make budget deficit permanent or would render a future tax reduction impossible. He knew very well that the program was far from its successful conclusions and there would be many obstacles along the road, but he was as optimistic as he had been in the beginning. One such issue was the state officials. On December $31^{\text {st }}, 2,780$ state employees got their notice, in addition to the 6,991 who had received it on June $30^{\text {th }}$. About 1,000 posts had been abolished since June $30^{\text {th }}$. But as Smith noted, this was nothing compared to what should be done, but such reduction could only come over a much longer period. ${ }^{654} \mathrm{As}$ far as treaty charges were concerned, Hungary had paid the counter value of the daily 880 tons of coal to Yugoslavia, and Smith told the Hungarian government that it should suspend such daily deliveries to its southern neighbor for December. ${ }^{655}$ The British minister reported that Smith confirmed to him in person that the general financial situation was healthy and hopeful, and he had "great faith in the in the capacity and intentions" of the new Finance Minister, János Bud. ${ }^{656}$

654 All the information in the paragraph is from Smith's Eighth Report, LNJ, $6^{\text {th }}$ Year, No. 3, March 1925, 397-408.

655 Smith to the Reparation Commission, December 15, 1924, OV9/437, BoE.

656 Barclay to Chamberlain, December 19, 1924, C19232/37/21, 9909, F0371, TNA. Bud assumed the post on November 25, 1924, and held it until September 5, 1928. 


\subsection{The Year of 1925}

The first month of January brought news not closely related to the reconstruction program. As far as this was concerned, Smith's ninth report informed everyone interested that in Hungary the multiplier was further reduced reaching 14,800 paper crowns on February $1^{\text {st }}$. This was finally on roughly par with its real value. Gross receipts showed a record so far and deposits in the banks kept growing. Expenditures were $20 \%$ in excess of what planned originally, but this was amply compensated for by the large surplus in revenues. However, as was now his custom, Smith could not refrain from noting that "there is no reason to expect that the causes that have brought about this surplus will continue to operate indefinitely, or to assume that the original programme of reform and economy is less urgent than it was when the Reconstruction Law was passed." 657 On the other hand, strikes made life more difficult for everyone. First it was the taxi drivers' strike in Budapest between December 30, 1924, and January 8, 1925, followed immediately by a strike in the coal mines in Pécs. Finally, work resumed four days later, because they were granted a $10 \%$ bonus. ${ }^{658}$

The real sensation, and really bad news, was that Smith got seriously ill. The pace at which he had been working started to take its toll. When he was about to start his journey to Hungary, he was characterized as "a man of abounding health and vigor." ${ }^{659}$ The constant hard work that he had been doing so conscientiously attacked his health in the beginning of the New Year, and he simply "blew up."660 On January $14^{\text {th }}$, Smith sent a telegram to his sister saying that he was not well, but he said it was nothing serious. ${ }^{661}$ On the same day, however, the CommissionerGeneral had to move to a sanatorium in Budapest where the doctors predicted a two to three week period of rest. ${ }^{662}$ Rumors started right away. The New York Times, for instance, referring to governmental circles, reported that there was no hope that Smith would carry on his work and after the required months of cure he would resign and return to the United States. ${ }^{663}$ To counter such unfounded rumors, Tyler quickly had a statement issued through the Hungarian Telegraphic Agency that "Jeremiah Smith about whose health alarming reports have been circulated abroad, is in reality taking a short rest and will resume his work in

657 Smith's Ninth Report, LNJ, 6 th Year, No. 4, April 1925, 545-53.

658 Brentano to Hughes, February 12, 1925, 864.00/616, Roll 7, M. 708, NARA.

659 Boston Daily Globe, April 8, 1924.

660 Smith to Niemeyer, May 25, 1925, OV9/437, BoE.

661 The New York Times, January 15, 1925.

662 Magyarország, January 15, 1925, XXXII/11.

663 The New York Times, January 15, 1925. 
the course of a few days." ${ }^{\prime 64}$ The breakdown of Smith's health was all the more unfortunate because he was facing heavy schedule. He was supposed to attend the meeting of the Committee of Control in Paris, but due to his illness he could not and the meeting was postponed to a later date. Also, in early February there was the League Council Meeting in Geneva, where Smith was expected to appear and give a report in person. In a few days' time Smith recovered to a satisfactory level and his Hungarian secretary György Királdi Lukács informed the press that Smith would be in Geneva on February $6{ }^{\text {th }}{ }^{665}$ Despite such reassurance soon another article appeared in The New York Times predicting Smith's resignation "according to reliable information gathered in diplomatic circles." 666 James Speyer was worrying lest he lost such an invaluable link to Hungary, where he hoped to make more money in the future, and asked Smith to contradict reports about his early resignation. ${ }^{667}$ Before Smith could reply, Speyer must have been happy to read that an unnamed British banker refuted the rumors about Smith's intention to resign his post in spite of his weakened health. ${ }^{668}$ Finally, it was Smith who put an end the speculations and denied all the rumors and declared that from March $1^{\text {st }}$, he would again resume his post with full responsibility. ${ }^{669}$

Smith appeared before the Council in Geneva on February $6^{\text {th }}$. Here he mainly dealt with the issue of state officials and their salaries. Since $60 \%$ of the budget expenditure went to the salaries of these people, obviously anything touching upon their issue was of great importance. The idea was to increase the salary of a group of the state employees by $15 \%$. It would have meant 34,000 people who made up, in the Commissioner-General's opinion, "an effective political machine."670 It was obvious that to have such a high number of officials amounted to luxury under the present circumstances, but for political reasons the government was reluctant to part with many of them. Finally, Smith suggested that "the Hungarian Government should be authorised to make an advance to the officials of five months' salary upon an increased rate of 15 per cent" involving "an expenditure of 9 million gold crowns." ${ }^{671}$ Salter would have

664 Tyler to Felkin, January 17, 1925, T. II. Incoming and outgoing telegrams, September 24-June 26, C. 120, Financial Reconstruction of Hungary, LNA; Press communiqué, January 17, 1925, P.III. Press communiqués, C. 117, Financial Reconstruction of Hungary, LNA.

665 Magyarország, January 28, 1925, XXXII/22.

666 The New York Times, February 6, 1925.

667 Speyer to Smith, February 6, 1925, T. II. Incoming and outgoing telegrams, September 2, 1924-June 30, 1926, C. 120, Financial Reconstruction of Hungary, LNA.

668 Wall Street Journal, February 10, 1925.

669 The New York Times, February 12, 1925.

670 Minutes of the Seventeenth Session, Second Meeting, February 6, 1925, F. /17 th Session/P. V. 2(1), LNA.

671 Minutes of the Seventeenth Session, Eighth Meeting, February 10, 1925, F/17 th Session/P.V. 8(1), LNA. 
liked to see a bonus instead of an advance, but the Chairman of the Financial Committee thought it should fall under the decision of Smith which one to choose, but the sum was not to exceed 7.5 million gold crowns ( $\$ 1.5$ million) and was only for six months. ${ }^{672}$ On the question of 15 million gold crowns ( $\$ 3$ million) for agricultural loan, upon Smith's suggestion, however, the Committee decided not in Hungary's favor. The ruling was that it was not possible to include such an amount of capital expenditure in the budget and could be only discussed if the Hungarian government provided a detailed plan as to its utilization. ${ }^{673}$ Therefore, for the Hungarian government the February meetings in Geneva was a mixed success, but Bethlen still warmly praised Smith's work and emphasized that Hungary could thank a lot to the American Commissioner-General. ${ }^{674}$

Jeremiah Smith, Jr. did not return to Hungary right after the conclusion of the official agenda. He decided that he needed some more rest. He chose to spend two weeks at Territet, close to Geneva. He wrote a letter to Norman to inform him about the situation in Hungary. He said the Hungarian population was "already heavily taxed - if not overtaxed," and that he could not conceive of anyone lending the city of Budapest a loan at present. ${ }^{675}$ The letter was the first he had written in a month and it was a very good testament how much he did need physical rest. The words he produced were misshapen, sometimes hardly decipherable, and they showed a severe strain on the author. Whatever the sickness might have been, Smith was still suffering from poor eyesight. ${ }^{676}$ Toward the end of the month he had regained enough of his energy to go to Paris and take part in the postponed meeting of the Committee of Control. Only then did he return to Budapest on March $7^{\text {th }}$. Although improved in health, he worked less than formerly. He decided that the best thing for him would be a longer vacation in the United States and made preparations to leave for six weeks in early April. ${ }^{677}$

This period was the low point for Smith and not only from the state of his health. For the first time he was the subject of attack, a phenomenon so far unheard of. The incident took place on February $20^{\text {th }}$, at a district political banquet of the Democrats of Budapest, and the person criticizing Smith was Vilmos Vázsonyi of the National Democratic Party, also a member of the National Assembly. Although the speech was severely criticized by Pester Lloyd, it evoked no comment in other papers. ${ }^{678}$ In addition, Smith was staying in Switzerland

672 lbid.

$673 \mathrm{lbid}$.

674 Pesti Hírlap, February 14, 1925, XLVII/36.

675 Smith to Norman, February 15, 1925, OV33/73, BoE.

$676 \mathrm{lbid}$

677 Brentano to Kellogg, April 10, 1925, 864.00/629, Roll 7, M. 708, NARA.

678 Brentano to Kellogg, March 11, 1925, 864.00/622, Ibid. 
recovering, and had no chance to defend himself if he wanted to. To make things worse, shortly after his return to Hungary, Pál Sándor of the Liberal Citizens' Party attacked the Commissioner-General's work, accusing him of letting Hungary to be subjected to financial oppression. ${ }^{679} \mathrm{His}$ accusation appeared on the front page the next morning. He was quoted saying, "Jeremiah Smith is here to make sure that the sum that was given to Hungary would go to foreigners [...] He did not have the courage to say that he would not let the population to be racked [...] Smith is weak and has not done his duty." ${ }^{180}$ Although other papers defended Smith, the attacks must have hurt him. He had done all he could for this country and still there were a few persons disparaging his work and saying he wanted not the best for the country. If anytime, this would have been an occasion to resign in fact. But Smith was made of stronger stock and with the worst of his health problem behind him, these attacks, if anything, only made him want to work more and achieve good results. Brentano, the American minister in Budapest reinforced in a message to the State Department that the resignation of Smith appeared to be "entirely unfounded." 681

Among such circumstances Smith wrote his tenth report about the turbulent month of February. Here he started off with countering once more the charges that had surfaced. He emphatically denied that the program was impossible to carry out, that there was no sufficient cooperation between the Hungarian government, and that he would resign. In connection with the extra money to the state officials, he mentioned that in the end 95,000 of them will get relief from February through June. After deducting the 7 million gold crowns ( $\$ 1.4$ million) this action would consume, there would still remain a comfortable surplus. Smith dealt with the State Ironworks in this report. The earlier experienced phenomenon also held true here, that is, the expenses on the officials and pensioners were about twice as much compared to the pre-war period. Also, while in 1913 there was a surplus, now the industry could boast of a deficit five times the amount of the earlier surplus. In addition, Smith was of the opinion that there were too many people in active employment and the industry produced more than what could be realistically sold. Good news was also announced. The multiplier was further reduced to 14,600, and the prospects for a bountiful harvest were good, which in the case of Hungary was always very important. On the other hand, despite some decrease in the prices of textile, clothing, and some manufactured articles, these were still higher than in France, Italy, Austria, and often higher

679 Brentano to Kellogg, April 10, 1925, 864.00/629, Ibid; Barclay to Chamberlain, March 12, 1925, C3858/260/21, 10772, F0371, TNA.

680 Magyarország, March 12, 1925, XXXII/58.

681 Brentano to Kellogg, March 11, 1925, 864.00/622, Roll 7, M. 708, NARA. 
than in Great Britain and the United States. ${ }^{682}$ This was partly a result of the new decree according to which import duties were raised on 36 articles between 20 and $1,500 \%$, including textile articles, plate-glass, iron and steel pipes, safety razor blades, razors, and cutlery. ${ }^{63}$ This was evidence that things were still in need of improvement and the commercial treaties the League of Nations had put so much emphasis on, first and foremost with neighboring countries, were far from being concluded.

Part of the answer to Hungary's reluctance to conclude such trade agreements was the idea of economic nationalism, which was typical in Hungary, although this was not the exception in Central Europe in the 1920s, and later as well. Even though the League of Nations tried hard to press Hungary and other countries into this direction, it eventually failed to counter this trend. The idea behind this economic nationalism, namely that Hungary might be largely self-sufficient was not rooted in realistic ideas. That is one of the reasons why Hungary was slow in arriving at commercial treaties with various other European countries. Being an agricultural country, relatively backward in industry, Hungary, just like other Central European countries, would have needed more eagerly to join the circulation of free trade on the continent. Various hikes in tariffs over time did not help to create a healthier economic environment.

March was the last full month Smith had spent in Hungary before he left on vacation to the United States. His next report reflected a successful Hungary on the road to full financial maturity. True, for the first time since October a deficit was to be present in the monthly budget, to the extent of 1.6 million gold crowns (\$320.000), but it was normal and was expected. There was also some decrease in the pledged revenues, but the sum alone in March was enough to cover $60 \%$ of one year's service of the loan. The state budget for the 1924/25 financial year showed a deficit of 99,930,500 million gold crowns (\$20 million), a measure the National Assembly accepted on March $15^{\text {th }}$, and a figure that was just under the 100 million mark provided for by the Reconstruction Law. With all these good results, during the month Smith consented to certain money withdrawals by the government from the forced loan account. He allowed for 30 billion paper crowns $(\$ 411,000)$ as a loan for the purchase of livestock, 6.8 billion $(\$ 93,000)$ as a loan to the Pest Comitat Irrigation Company to bring wasteland under cultivation, and 8.5 billion $(\$ 116,000)$ to continue to build small lodging houses. Toward the end of March, the National Bank reduced the discount rate from 12 $1 / 2$ to $11 \%$. Semi-officially it was admitted that it was a somewhat experimental step and depending upon a positive reaction from the market, further reduction

682 All the information in the paragraph is from Smith's Tenth Report, LNJ, $6^{\text {th }}$ Year, No. 5 , May $1925,661-72$.

683 Brentano to Kellogg, March 11, 1925, 864.00/622, Roll 7, M. 708, NARA. 
would take place. Also in the category of good news, a commercial treaty was signed with Poland on the most-favored-nation principle, the biggest advantage of which would be for Hungarian wine. It was also good news that both wholesale and retail prices showed a significant decrease in the first months of the year ${ }^{684}$ Despite his negative views earlier, the British adviser to the National Bank was also optimistic concerning the overall picture. In his memorandum he concluded the following:

It is fairly safe to assume that nothing short of an international catastrophe can now shake the stability of the Hungarian Crown. If an odious comparison were permissible it might even be said that Hungarian currency is in fact - as it certainly is in the general opinion - more secure than Austrian currency. ${ }^{685}$

He also mentioned that "the weak spot of Hungarian public finance" was that $60 \%$ of the expenditure went for the payment of the personnel. ${ }^{686}$ Another significant event was James Speyer's latest visit to Hungary. He timed it well just in time before Smith was leaving for a longer vacation. He stayed in Budapest for three days late March, and met with Smith among others. ${ }^{67}$ He was again working on the preparation of another loan scheme for Hungary. Smith finally left Hungary for his long awaited holiday. Although he felt much better than during the winter, he was far from total recovery, and was looking forward to visiting his home. ${ }^{688}$

Smith arrived in the United States on April $15^{\text {th }}$. This was the first time he had traveled home since being appointed back in April 1924, so it was understandable that he craved the quiet of his home surroundings. While at home, he had to deal with his health issue as well. He saw a number of American doctors who agreed that he never had a hemorrhage of the brain at all. They claimed that the Hungarian diagnosis was wrong though the treatment prescribed was right. According to them, Smith had a "circulatory spasm," which meant that the circulation went wrong in certain parts of his body, as a result of advancing age and fatigue. His sight got bad and a blue spot appeared in each eye. The doctors

684 All the information in the paragraph is from Smith's Eleventh Report, LNJ, $6^{\text {th }}$ Year, No. 6, June 1925, 813-21.

685 Siepmann's memorandum on the Hungarian situation, March 15, 1925, C4189/260/21, 10772, FO371, TNA.

686 lbid.

687 Speyer to Smith, March 19 and March 23, 1925, T. II. Incoming and outgoing telegrams, September 2, 1924-June 30, 1926, C. 120, Financial Reconstruction of Hungary, LNA. 688 Smith to ter Meulen, March 23, 1925, C.III. (11) Correspondence - Mr. C. E. ter Meulen, C. 111, Financial Reconstruction of Hungary, LNA. 
told him that he needed much more rest, which was bad news in light of the pace of the first eight months spent in Hungary. ${ }^{689}$

Also, he was target of some newspaper attention. One thing he was asked about was his refusal for compensation in the beginning of the job. He had this to say in connection with the topic: "I did it because I live simply and require little for my own needs. It hardly seemed fitting that I should urge sacrifice and economies upon the Hungarians and yet not show the same spirit myself." 690 He was also busy countering earlier accusations surfacing in the American press that he had problems with the Hungarian government. He praised the cooperation between the Bethlen government and himself and gave out optimistic vibrations about the Hungarian finances. ${ }^{691}$ Coincidentally, an article of the Hungarian Prime Minister appeared also in the April issue of Foreign Affairs. Smith's interviews had been a great prelude to what Bethlen wrote. Aside from the political aspects that were phrased in a way to give the biggest possible legitimacy to the Hungarian government, Bethlen also played the financial card:

I cannot sufficiently emphasize to my foreign readers the fact that even in her present form and structure Hungary offers the most favorable field conceivable for the investment of foreign capital. The industrial, commercial and agricultural possibilities open here to foreign capital and foreign enterprise are practically unlimited; all that is required is for them to be energetically seized and transformed. I am convinced that the financial world of America [...] will on this occasion too discover Hungary - which to a certain extent is perhaps still a terra incognita for American business menis worthy of interest and study. ${ }^{692}$

As can be seen, he did everything possible in his power to induce American investors to look to Hungary as a lucrative spot, and Smith's widely quoted reports about the positive financial reconstruction had been preparing the ground for such plans.

No matter how apolitical Smith was and how much he wanted to avoid even the shadow of any charges that he was dealing with politics, sometimes he had to step up and say a few words in connection with such a subject. The incident that served such a situation was the Károlyi propaganda in the United States that Hungary should get no more loans because it would be spent on war intentions

689 As for Smith's health, the information came from Smith to Siepmann, in Siepmann to Norman, May 19, 1925, OV33/39, BoE.

690 Boston Daily Globe, April 15, 1925; The New York Times, April 16, 1925.

691 Wall Street Journal, April 16, 1925.

692 István Bethlen, "Hungary in the New Europe," Foreign Affairs 3 (April 1925): 455. 
only. ${ }^{693}$ He countered such charges with the logical assertion that only through him could the government have access to money to spend, but he would only provide money for the sensible financial and economic goals. He was quoted in Time magazine as saying: "The Government has no capital at its disposal which it could use without my knowledge for secret armaments and the rumors about preparation for war are nothing but naïve horror stories." 694 Smith defended the Bethlen government as well: "The Hungarian Government has risked even political unpopularity to cooperate with me, a fact of which I can speak only the greatest appreciation." 695 Whether he agreed with the Bethlen government politically is a different topic. But he certainly had found a cooperative partner in Bethlen and his government, a fact that he highly cherished, especially compared to what Alfred Zimmerman was subjected to in Vienna.

The report covering the month of April, when Smith was staying in the United States, showed further progress in the reconstruction program. Smith consented to further money withdrawal by the government from the forced loan account in April: 8.5 billion $(\$ 116,000)$ for small lodging houses and 12.8 billion $(\$ 175,000)$ to continue the building of a powder factory. Wholesale prices showed a further decrease, a continual occurrence since the start of the year. Although the revenues declined in a fashion Smith had warned about earlier, this phenomenon did not give reason to be alarmed, because the reasons were largely attributable to seasonal changes. Since the start of the reconstruction, the number of bankruptcies had been relatively low, 109, although so-called insolvencies had been abundant, 912. The big news was that Great Britain had reached gold parity again and it meant that Hungary, its crown pegged to the pound, got on gold value as well. This was naturally taken as good news. The crown had been stable for many months now and the debate had begun that how soon a new currency unit should be introduced. ${ }^{696}$ So, when Smith returned to Hungary on May $15^{\text {th }}$, he had every reason to be "very cheerful and quite well." 697 His words that he was happy to be back in Budapest and was doing his

693 Count Mihály Károlyi was originally not granted visa to enter the United States, where his wife stayed ill, but later this was modified and he was permitted to visit but was not allowed to speak or write for publication while in the United States, a condition to which he agreed. When this sparked some debate in Congress, Hughes claimed that the action was taken under war legislation, which still survived. Finally, he was allowed to reply to attacks made against him on March 7, 1925, at a lunch given in his honor by the American Civil Liberties Union. His serious speech impediment made it unlikely for anyone to understand what he was going to say, anyway. Howard to Chamberlain, February 27, 1925, 3303/434/21, 10777, FO371, TNA.

694 Time, May 11, 1925.

695 lbid.

696 All the information in the paragraph is from Smith's Twelfth Report, LN], $6^{\text {th }}$ Year, No. 8 August 1925, 1095-1104.

697 Goode to Norman, May 19, 1925, OV33/73, BoE. 
job with great pleasure pleased everyone reading front page news. ${ }^{698}$ Smith also told Siepmann after his return that he had more will to learn about Hungary and to take an interest in forms of investment, a feature not present a year earlier. ${ }^{699}$

In his report for the month of May, Smith wrote that due to a falling-off in customs receipts, the smallest amount of pledged revenues was realized since last September. Still, owing to the good overall picture and realistic optimism about the future, Smith consented to an advance of 24 million gold crowns (\$4.8 million) to certain towns, counties, and drainage societies for such work. Wholesale prices had been decreasing continually since the start of the year and deposits in the banks kept growing. As a sign of more healthy circumstances prevailing, on May $28^{\text {th }}$, the Bank's discount rate was reduced from $11 \%$ to $9 \%$. Behind the step was a clear initiation by the National Bank to induce the other Budapest banks to follow suit and lower their interest rates in order to help enterprises to get easier access to credit. Unfortunately, such interbank cooperation brought no encouraging results. ${ }^{700}$ Smith confirmed the overall good results in a personal letter to Otto Niemeyer, but complained that prices, despite a 15\% decrease since last July, were sometimes still higher than in New York. ${ }^{701}$ He added that the Hungarian government had provided "every evidence of goodwill and support [...] and they have really done very well up till now." ${ }^{702}$ The foreign adviser, however, started to formulate negative criticism again. In a letter to Norman, Siepmann wrote his mentor that he was beginning to be afraid of what he called "the free lance campaign of borrowing" by Hungary. ${ }^{703} \mathrm{He}$ had a point. Just as the Bethlen article was a good indication of such initiatives, Hungary did indeed offer itself for foreign capital, mostly American, without paying too much heed for possible future consequences. What helped such a course was partly the opinion held by the banker segment in the United States. As an analyzing company concluded, of the foreign loans raised in the United States four were entitled to a preferred rating (the Austrian, the Hungarian, the German, and the Czech issues), but "the most attractive" was the Hungarian bond. ${ }^{704}$ One of the reasons on which they based this conclusion was that the Hungarian reconstruction was under the supervision of Smith.

698 Magyarország, May 19, 1925, XXXII/112.

699 Siepmann to Norman, May 19, 1925, OV33/39, BoE.

700 All the information in the paragraph is from Smith's Thirteenth Report, LNJ, $6^{\text {th }}$ Year, No. 8, August 1925, 1105-16.

701 Smith to Niemeyer, May 25, 1925, OV9/437, BoE.

702 lbid.

703 Siepmann to Norman, May 19, 1925, OV33/39, BoE.

704 W. A. Harriman \& Co. Analyses, June 5, 1925, L.V. (2) May 1925-Dec 1927, C. 114, Financial Reconstruction of Hungary, LNA. 
Speaking of American capital, Speyer was as active as ever. He wanted to confer with Smith in person while the latter was still in the United States, but he missed him by one day and the banker had to rely on letters again. The subject was a possible agricultural loan for Hungary, which earlier the League refused to advance from the loan money. Speyer asserted that William Goode's plan to raise the money in London was impractical, since the London market was closed for the season, and concluded that "it naturally follows that our market here is the principal one to rely on for this and similar foreign businesses during this period. " ${ }^{705}$ He reiterated in the same letter that it was "an essential condition for us that you approve of the plan. " ${ }^{706}$ Speyer gave the bankers' responsibility toward the League as a natural reference to the approval of the League Commissioner. Smith in his answer, however, categorically objected to his name being used in connection with loans falling outside the League. He was quite afraid that his name referred to in that fashion "would be misunderstood by people who ought not to draw erroneous conclusions but who probably would do so."707 Finally, Speyer had to settle for the municipal loan for Hungarian cities, which was good business for the American banking house.

Although Smith did not respond to Speyer's inquiry about his health, in a personal letter to Elliot Felkin, member of the Financial Committee, he wrote about his health condition. His answer was revealing: "I am a good deal better than I was, but I am not entirely recovered yet and don't expect to be for a good while. I have my ups and downs and some days think that it is quite impossible to continue with the work, and other days think quite differently about it."708 This was the closest that Smith had ever come to expressing doubts about his physical capability to go on with the League job. It can be attributed only to his dogged persistence and his high sense of responsibility that he kept on working with the same amount of zeal and optimism. Naturally, he had Tyler and Charron to rely on. He also confided in Siepmann concerning his health, and the Briton duly sent the information to Norman. According to Siepmann, Smith would not be "quite his old self," would take more care of himself, would work less, and was already planning to go back to the United States in the middle of November for two months. ${ }^{709}$ With lingering problems about his health put on the sideline, he started to look after the state finances of Hungary with renewed vigor and was preparing for the next League Assembly

705 Speyer to Smith, May 15, 1925, A. IV. a. Agricultural credits, mortgage bonds, land reforms, C. 106, Financial Reconstruction of Hungary, LNA.

706 lbid.

707 Smith to Speyer, May 30, 1925, Ibid.

708 Smith to Felkin, May 22, 1925, C.III (6) Correspondence - M. A. E. Felkin, C. 111, Financial Reconstruction of Hungary, LNA.

709 Siepmann to Norman, May 19, 1925, OV33/39, BoE. 
meeting in early June in Geneva, which Tyler predicted would be "a critical juncture."710

Smith was a feature of the second League Assembly of the year and he appeared before the Council on June $9^{\text {th }}$. This was the official platform to summarize the first year of reconstruction for everybody interested. Naturally, the figures were known thanks to the monthly reports of Smith; still, such a gathering offered a more prominent stage to highlight the most important achievements and to introduce the results of the first year to the world at large. The most spectacular element without any doubt was the fact that the 100 million gold crowns estimated for the deficit for the first year had not been drawn upon and there would be a surplus of 63 million gold crowns ( $\$ 12.6$ million) instead..$^{71}$ The Financial Committee decided that this surplus and a further 30 million gold crowns ( $\$ 6$ million) could be used for productive purposes, subject to the agreement of the Commissioner-General. ${ }^{712}$ The Council approved that for about 95,000 state officials the increase in salaries of $15 \%$ in February should be permanent to the amount of 20 million gold crowns, even if it meant a 15 million ( $\$ 3$ million) extra burden on the budget annually. ${ }^{713}$ The low point of the report was the tax question. It remained very substantial, 75 gold crowns (\$15) per head, which was extremely high for Hungary and meant $135 \%$ of the pre-war level. As Smith put it in Geneva, "the taxation in Hungary has reached the limit of possibility and capacity. ${ }^{1714}$ It was obvious that sooner rather than later some tax reduction was necessary and the government started to work on it.

In addition to the Council resolutions, Smith mentioned the following points in his report for June. The results of the 1924/1925 financial year altogether, and somewhat surprisingly, made Smith conclude that "it is certain that there will be a substantial surplus-a result far beyond the most sanguine expectations entertained by anyone a year ago." In the first year of the reconstruction program retail price index decreased by $14 \%$, while whole-sale prices fell by $8 \%$. The average wages reached the prewar level, but in terms of purchasing powers they still lagged behind. The estimate for the financial year of 1925/26 showed a budget surplus of 27.5 million gold crowns (\$5.5 million), the government using a multiplier of 14.500 . Commercial treaties were concluded with Greece and Spain, on June $3^{\text {rd }}$ June $17^{\text {th }}$, respectively, with the most-favored-nation clause. Deposits in the banks grew further, which was a clear indication of the trust

710 Tyler to Mildred Bliss, April 15, 1925, Tyler Papers.

711 LNJ, 6th Year, No. 7, July 1925, 859.

712 Report of the Committee, June 11, 1925, C. 335 (I). M. 116. 1925, LNA.

713 LNJ, 6 ${ }^{\text {th }}$ Year, No. 9, September 1925, 1243-1244.

714 Pesti Hírlap, June 6, 1925, XLVII/125. 
of the public. Balance available from the loan on June 30,1925, amounted to $182,652,607.41$ gold crowns $(\$ 36.5$ million $) .{ }^{715}$ With the end of the first financial year of the reconstruction period, all expectations had been exceeded by the results and the optimism that, for example, Jeremiah Smith, Jr. had shown all along, seemed to be paying off and materialize. A significant intergovernmental agreement was the Treaty of Friendship, Commerce, and Consular Rights, signed at Washington, June 24, 1925. ${ }^{716}$

As for Speyer, he did not give up and now made inquiries at the League of Nations as to how the Commissioners-General could be involved in advertising new loans. Since Smith wanted to avoid appearing in the prospectus of any possible loan for fear of controversy, Speyer hoped the League would ease such worries. Although Alfred Zimmerman would have gone further, Smith, whose position was obviously more complicated in terms of American loans, consented only to a short private letter to the issuing house that could be attached to the prospectus: "We are authorized to state that from the point of view of the League of Nations reconstruction plan for Austria/Hungary there is no objection to this loan. ${ }^{717}$ He was adamant that for American issues this formula would be sufficient. So Speyer had achieved some progress, but he wanted the best insurance for any business. In light of the State Department's somewhat strict attitude about foreign loans, he asked Smith to issue a statement that he encouraged the pending city loans for Hungarian cities by Speyer \& Co. He basically begged for Smith's help. "We fear we shall have to abandon this business unless we get from you some such statement as above. Please help all you can." ${ }^{718}$ Smith in the end did not provide more what he thought was moral and legal, but Speyer did not need to fear failure. On July 1, 1925, the $\$ 10,000,000$ Hungarian Consolidated Municipal Loan by Speyer $\&$ Co. was signed and advertised in New York Papers. ${ }^{719}$ The loan

715 All the information in the paragraph is from Smith's Fourteenth Report, LNJ, $6^{\text {th }}$ Year, No. 9, September 1925, 1242-53.

716 For the text of the treaty, see FRUS, 1925: 2:341-54. Right after the signing of the treaty, however, Kellogg signaled that the Senate will add certain reservations concerning Hungarian immigration to the United States and how long the treaty will remain in force. Hungary accepted such reservations. Kellogg to Széchényi and Széchényi to Kellogg, June 24, 1925, and Brentano to Walkó and Walkó to Brentano, September 4, 1926, Ibid., 354-57. 717 Niemeyer to Norman, June 10, 1925, OV33/73, BoE.

718 Speyer to Smith, June 10, 1925, T. II. Incoming and outgoing telegrams, September 2, 1924-June 30, 1926, C. 120, Financial Reconstruction of Hungary, LNA.

719 The New York Times, July 5, 1925. The different papers relating to the loan can be found in 332 and 334-38, K 269, Finance Ministry, General Papers, HNA. The cities, altogether 48 of them, applied for 139,904 gold crowns initially, of which amount 104,166 was planned to be spent on constructive investments. The government finally allowed an application for a loan of 75,865 gold crowns. Elemér Inántsy-Pap, A magyar városok Speyer-kölcsönei [The Hungarian Cities' Speyer Loans] (Budapest: Home Printing House of Budapest, 1938)، 5, 10. 
was for twenty years and carried a $7.5 \%$ interest. ${ }^{720}$ Speyer bought the bonds at $82 \%$ and sold them for $89 \%$, thus realizing a comfortable profit. ${ }^{721}$ Therefore, it can be safely concluded that Speyer $\&$ Co. filled an important segment in the investors' camp providing loans for Hungary.

Despite its conspicuous role, the relationship between Speyer $\&$ Co. and the Hungarian government was not always harmonious, however. Sometimes there were serious frictions on account of business. For instance, Speyer was hurt because his offer for the upcoming Counties Loan, after the reconstruction program was successfully finished, was better than that of Rothschild's, still the Hungarian government chose the London house. This happened despite Speyer's repeated protests to the contrary and the promise of privileges earlier promised by Finance Minister Bud. In fact, according to Bud, the problem arose from Speyer's noncommittal attitude. Already during the Cities Loan, Speyer \& Co. was willing to negotiate about the price of issue on the very last day only. This time around, the American company did not go farther than verbal declarations despite several urgings from the Hungarian Finance Minister, who,

720 One year later, Speyer \& Co. was also the agent in floating a second series of the same type of loan, the Second Hungarian Consolidated Municipal Loan, which was issued September 1,1926 . This loan was for $\$ 6,000,0000$, for twenty years and with $7 \%$ interest. 721 The sum provided by the loan, however, did not prove sufficient for most of the cities involved, and new cities wanted to apply for a similar loan. So, the government raised the sum with 34,470 gold crowns. Inántsy-Pap, A magyar városok Speyer-kölcsönei, 12. Originally, the cities wanted much more, and the option was "offered to Speyer, without a time limit." Siepmann to Norman, May 31, 1926, OV33/42, BoE. It meant a further $\$ 6$ million from Speyer \& Co., which meant 30 million gold crowns. According to Article 6 of the first contract, the cities had to make an offer for Speyer $\&$ Co. first, and in case of identical offers Speyer $\&$ Co. was the house to conclude business with. This was basically a contractual repeat of the promise earlier made by the Hungarian Finance Minister. Thus Speyer $\&$ Co. was also the agent in floating the second series of the same type of loan, the Second Hungarian Consolidated Municipal Loan of $\$ 6,000,0000$, also for twenty years. This contract was signed on October 27, 1926, and the offer was quite decent. The interest rate went down to $7 \%$, the price of bonds Speyer $\&$ Co. paid was raised to $89 \%$ and the price of issue was $93.5 \%$, a spectacular difference compared to the first installment. From the second loan, less than $10 \%$ was allowed to be spent on nonproductive investments, while in the case of the first loan, this number was $25 \%$. Inántsy-Pap, A magyar városok Speyerkölcsönei, 16. Out of the total \$16 million, the cities received a net sum of 74,349.659 gold crowns (almost $\$ 15$ million). In the end, out of the $74,349.659$ gold crowns, $13,350.126$ were spent on nonproductive investments, and 60,999.533 on productive investments. Ibid., 20, 26. The cities did not always spend the money in a wise way. A typical example was that of the city of Miskolc, which after the two Speyer loans in 1925 and 1926, from which the city tried to finance too many things, was forced to take up a third loan to the amount of $\$ 800,000$, under strict conditions, in order to be able to repay the Speyer loans and keep financing the construction works under way and other various projects. Still, by 1931 the city defaulted and was unable to pay. In detail, see István Dobrossy. "Miskolc infrastruktúrájának modernizálása és a 'Speyer' bankkölcsön felhasználása (1925-1950) [The Modernization of the Infrastructure of Miskolc and Using the Speyer Loans]," In. Yearbook of the Herman Ottó Museums, XXXIII-XXXIV (Miskolc: 1996), 423-51. 
in the end, chose the Rothschild-Baring-Schröder group, which made a slightly worse offer. ${ }^{722}$ But the American banking house was way too important for the Hungarian government, Speyer's origins notwithstanding. William Goode, the British adviser on the Hungarian government's payroll, warned earlier, too, that "It is, of course, important to retain Speyers' goodwill." 723 For Hungary, it was simply very important to have a bank in the United States they could count on. Racial views were forgotten in such cases. Those only had place within the borders of the country.

Aside from the Speyer Loan, not much happened in July. The final statistics for the 1924/25 fiscal year showed a budget surplus of roughly 63 million gold crowns (\$12.6 million). This information in itself was not very telling. Obviously, just the pure fact that there was a significant surplus on hand made Smith, the Hungarian government, and the League all satisfied, because it gave clear evidence that the program was on the right track. Further boost emanated from the fact that foreign credit had started to come, mostly in short-term form, with a few long-term ones, chiefly from the United States. Even more importantly, so far Hungary had avoided overborrowing. The National Bank's metal reserves had doubled since its opening and this made Smith conclude: "It is safe to say that the Hungarian crown is now secure not only in fact but also in the confidence of the public." Commercial treaties had been concluded with Poland, Greece, Spain, and Italy. In terms of foreign trade though, the most important partners were Austria and Czechoslovakia, Germany being a distant third, countries with which there were no treaties concluded yet. Wholesale prices showed a further decrease, while deposits in the banks grew and reached an amount five times more than a year before. All these data and symptoms meant that Hungary was "far in advance of the Reconstruction Plan," which made Smith look to the future with "confidence and great hope."724 The multiplier was officially reduced from 17,000 to 14,500 for the payment of taxes, public dues, and rentals, and as of July $1^{\text {st }}, 2,000$ more officials were retired..$^{725}$

In a confidential memorandum, Smith also made account of the expenses of the commissariat. It was about $\$ 37,000$, and as far as his own expenses were concerned, he wrote this: "The Commission-General has been furnished

722 Bud to Goode, August 5, 1926, 1/22/1926/91-92, K 276, Bud Papers, HNA. The loan issued in London by the Rothschild group was successful and was oversubscribed twenty times. There was another British consortium, the British Overseas Bank and Helbert Wagg $\&$ Co., which complained of not receiving the contract despite of offering a higher bid than the Rothschild group. However, the prestige of the Jewish banking house seemed to be overwhelming for Hungarian officials. Goode to Bud, July 30, 1926, /87-89, Ibid.

723 Goode to Bud, November 20, 1925, 1/7/1925/8, Ibid.

724 All the information in the paragraph is from Smith's Fifteenth Report, LNJ, $6^{\text {th }}$ Year, No. 11, November 1925, 1637-46.

725 Brentano to Kellogg, July 31, 1925, 864.00/656, Roll 7, M. 708, NARA. 
by the Hungarian Government with a residence and a motor car, but has not drawn from the Government the full amount of $\$ 18,000$ per year to which he is entitled, having taken only his living expenses in Budapest, which are at the rate of substantially $\$ 200$ a month."726 This summary showed well that Smith indeed tried to save as much money as possible and make a good example by not accepting his salary. Almost as a symbolic close for the 1924/25 fiscal year, once again a small commemoration was held at the George Washington statute on account of July 4, where both Brentano and Smith appeared. It was a rare occasion where photos were actually taken of Smith and later they also appeared in newspapers. ${ }^{727}$

The August report shed some light on the revenues in term of taxes. In the $1924 / 25$ fiscal year, out of the whole revenues, direct taxes were responsible for about one fifth, whereas turnover taxes produced about a quarter of the total. This was somewhat surprising and not necessarily welcomed news. The direct taxes had been expected to produce a larger percentage and it was not clear why the $36 \%$ planned in the reconstruction plan achieved only $20 \%$ of all revenues from various taxes. As part of this result and of the overtaxation of the population Smith had already complained about, the turnover tax was reduced from $3 \%$ to $2 \%$ as of August $1^{\text {st }}$. The other surprisingly large proportion of such revenues was the customs, which produced more than twice as much as planned. This was not necessarily good news because of its negative effects on the domestic trade of the country. The Council had agreed that the Hungarian government could make capital investments for 70 million gold crowns (\$14 million). In his sixteenth report, Smith listed under thirteen headings the planned program for the first half of the 1925/26 fiscal year. ${ }^{728}$ As Smith notified Finance Minister Bud, he accepted every suggestion of the government, except the 68,000 gold crowns $(\$ 13,600)$ for exploration purposes, which he did not accept as capital investment.729 The rest of the August report made also mention of negotiations with France and Turkey for commercial treaties that had been concluded, and about the now standard feature of the reconstruction program, namely that wholesale prices showed a further decrease and deposits in the banks grew anew. ${ }^{730}$ In addition, since last September, the number of unemployed had been the lowest in August,

726 Smith to Salter, September 24, 1925, E.I.-1. Expenses, July 1, 1925-June 30, 1926, C. 113. Financial Reconstruction of Hungary, LNA.

727 Pesti Hírlap, July 7, 1925, XLVII/149; The New York Times, August 9, 1925.

728 All the information in the paragraph is from Smith's Sixteenth Report, LNJ, $6^{\text {th }}$ Year, No. 11 , November 1925, 1647-57.

729 Smith to Bud, August 25, 1925, B.V. (3) Budget Surplus Account, 1924-25, C. 109, Financial Reconstruction of Hungary, LNA.

730 Smith's Sixteenth Report. 
but this was largely thanks to the harvest season, when many unemployed people found temporary job. ${ }^{731}$

In August, not only Smith wrote about the Hungarian financial landscape. Prominent experts came to study the financial situation in Hungary. Professor Allyn Young of Harvard and a Belgian financial expert, Maurice Frère, spent a little bit over three weeks in Hungary going over all the possible details of the present financial and economic life in Hungary before traveling to Geneva to give verbal summary of their report. ${ }^{732}$ The report was not intended to be as fully detailed as the Layton-Rist report in the case of Austria, which was the basis for this study to be carried out, but rather to inform the Hungarian CommissionerGeneral. It is worth mentioning the main conclusions of the report, which was finished on August $24^{\text {th }}{ }^{733}$ As far as population was concerned, the authors claimed that the ratio of urban population was too high and this would lead to such results as a relatively low level of real wages, a relatively low industrial output per capita, a wasteful multiplication of middlemen, and a tendency to rely upon state aid rather than upon productive efforts. The report emphasized that agriculture should receive four times as much weight as industry. Light was also shed on the well-known fact that "the present level of money wages in Budapest [wa]s extremely low [...] In most of the industrial countries of Europe they [we] re distinctly higher." In the realm of taxation, the report echoed Smith in the assertion that the country was heavily taxed. The suggestion was a new tax form along new lines in place of the present and much discredited income tax. The most important point was, especially in hindsight, that Hungary needed foreign capital to complete the economic recovery. The following observation was made: "The danger lies, not in borrowing, but in over-borrowing or in borrowing for non-productive purposes [...] The real danger is from such borrowing as might be undertaken, not in order to reap business profits, but to "better the situation."' As can be seen, the report did not provide much new information; it rather confirmed earlier observations by others, Smith among them. Since the overall outcome of the report was optimistic and the dangers it listed seemed not present at the moment, it boosted the already successful reconstruction program.

September was again the time for the usual pilgrimage to Geneva, where Smith was to give a summary of the past year in Hungarian finances. In front of the Council he claimed, "there is every reason to believe that the permanent

$731 \mathrm{lbid}$.

732 Smith to Slater, August 19, 1925, T. II. Incoming and outgoing telegrams, September, 1924-June, 1926, C. 120, Financial Reconstruction of Hungary, LNA.

733 The whole report can be found in 3/1921-1928 B/2.570/925, K 468, Bethlen Papers, HNA. If not mentioned otherwise, the information discussed in the paragraph is from this source. 
equilibrium of the Hungarian State finances will be maintained."734 The next day he appeared at the Financial Committee to give a more detailed report. Smith informed the Committee about the main results of the first year, which were "far beyond what anyone could have foreseen." 735 As he explained, all this was achieved by the immense increase in revenues, 40-50\% more than the estimates, which was attributable to the stabilization of the crown, despite the $10 \%$ increase in expenditure. ${ }^{736}$ He once again hammered at the heavy taxation in Hungary. Although the total taxation in Hungary amounted to 75 gold crowns (\$15) per head, much lighter than in Western European countries, when computed in percentage of the national income, the taxes proved high. ${ }^{737}$ The future also seemed promising. The harvest had been the best since the war, the economic conditions showed a slow but steady improvement, the estimates showed a balanced budget for the 1925/26 fiscal year, and all these fragments made Smith believe that the satisfactory condition at present was going to be permanent. ${ }^{738}$ The American again emphasized the cooperation he had received from the government, and praised the international effort brought on by the initiative of the League of Nations. ${ }^{739}$ Smith's statement was very favorably received not only by the League but also by Hungary as well. He was especially praised for the act when he countered the Little Entente delegate's charges that there was any secret item in the expenditures..$^{740}$

The Commissioner-General's report for September, as had been done on various earlier occasions, put a topic in the center. This time it was the question of taxation in Hungary. Based upon his calculations, the estimated per capita tax burden for the 1925/1926 financial year (60 gold crowns) was by and large the same as in the pre-war years. When compared to other European countries, the Hungarian tax burden seemed lightly. In Germany it was more than twice, in France two and a half times as much, the case was similar in Great Britain, and in Austria it was almost twice as much as in Hungary. However, it must be noted that the prewar taxes in the Austro-Hungarian Monarchy were higher than in most European countries, and Hungary being a chiefly agricultural country was not in a position to extract more money from its subjects. Moreover, in addition to state taxes, people were to pay local taxes as well, which meant, on an average, a further 12 gold crowns from the taxpayers. The rest of the

734 LNJ, 6th Year, No. 10, October 1925, 1355.

735 Statement of Smith, September 11, 1925, Financial Reconstruction of Hungary, Discussions at the $6^{\text {th }}$ Assembly, 1925. Doc. No. 46255, Registry Files, R. 301, LNA.

736 lbid.

737 lbid.

$738 \mathrm{lbid}$

$739 \mathrm{lbid}$

740 Pesti Napló, September 11, 1925, 76/203. 
report contained good news: For the first time since the war, August had showed a favorable trade balance ( +8.3 million gold crowns) thanks to the excellent harvest, which had been the best since the war; deposits in the banks grew and since last September, the number of unemployed had been the lowest, although due to seasonal works. ${ }^{741}$ To boost further confidence in what seemed a healthy business environment at work, the shares of the National Bank were issued on the Budapest stock exchange on September 21, 1925. ${ }^{742}$ All segments seemed to ensure that the second part of the reconstruction would be business as usual.

October was a dull month compared to some preceding ones. That was actually good news because it was further proof that the program was running smoothly and no unexpected obstacles arose. In his report pertaining to this month, Smith had only the usual good news to tell about wholesale prices, the number of unemployed, and deposits in the banks. The only really significant event was also good news. The National Bank's discount rate was further reduced, this time from 9 to $7 \%$. Behind this step the Commissioner-General surmised was the intention to keep the short-time foreign credits away as much as possible, and to induce Hungarians more to borrow money from the National Bank. ${ }^{743}$ Smith, who had a really amicable relationship with the government, tried to use his practical American mind and convince them to make the most of the idle money of the loan that was not needed because of the good budget figures. He explained to Speyer, when the latter had information according to which Smith had refused to give consent for using the said money, that he had been for some time urging the Hungarians to utilize some part of the reconstruction money mainly for temporary investment, but they were not willing to do so. ${ }^{744} \mathrm{As}$ Smith calculated, the Hungarian government might have been afraid that doing so would be illegal, so he thought of using the money only with the consent of the League of Nations. The sole purpose would have been to gain some money and not to boost the price of the Hungarian Bonds, although that was a possible consequence as well. ${ }^{745}$ Henry Strakosch absolutely resented the idea, because he saw in it only jobbing purposes. ${ }^{746}$

In the last week of October, as he had planned back in spring, Jeremiah Smith, Jr. once more traveled home to the United States. He was planning to spend two

741 Smith's Seventeenth Report, LNJ, 6 $6^{\text {th }}$ Year, No. 12, December 1925, 1759-1769.

742 Tamás Bácskai, ed., A Magyar Nemzeti Bank története [The History of the Hungarian National Bank] vol. 1. (Budapest: Közgazdasági és Jogi Kiadó, 1993), 549.

743 All the information in the paragraph is from Smith's Eighteenth Report, LNJ, $7^{\text {th }}$ Year, No. 2, February 1926, 241-48.

744 Speyer to Smith and Smith to Speyer, September 12, 1925, L. V. C-1, June 24-30, 1924,

C. 114, Financial Reconstruction of Hungary, LNA.

745 Smith to Norton, October 17, 1925, OV9/438, BoE.

746 Strakosch to Niemeyer, October 21, 1925, Ibid. 
months on vacation, a period that his battered health was in great need of. Before setting sail, he stayed a few days in London to confer with the principal actors. He had long talks with Montagu Norman, for example. Smith asserted that state of Hungary was such "as to justify and demand the termination of League control by the end of June 1926." ${ }^{\prime 74}$ The main points of these talks were the future of the Geldinstituteszentrale (a financial institution where public funds were kept outside the control of the National Bank) and the position of the Bank Adviser. In the former, the unanimous idea was that its role must be suppressed, while in the case of the Bank Adviser, the conclusion was that although the National Bank would be happy to have the Adviser for a prolonged time, the League had no right to renew the post. ${ }^{748}$ The question would come up at spring session of the League of Nations.

Smith's homecoming was inadvertently set up by a Hungarian. Gustav Gratz, former finance minister of Hungary, was the principal speaker at the annual meeting of the Academy of Political Science on October $28^{\text {th }}$, where he praised Smith and his work in Hungary. ${ }^{749}$ So, when Smith set on foot on his home soil after more than half a year again on November $6^{\text {th }}$, the ground was prepared. The main points and figures of his reports had been quoted in the leading newspapers, but since nothing special had happened in Hungary, only the continual good results, attention was somewhat lacking. With his relatively longer stay, Smith got again in the limelight, something he did not enjoy. He was seen by many as the ruler of Hungary in terms of monetary issues, which was true in many ways. However, when a leading paper asked what it was like to be the "financial czar of all the Magyars," he answered, "It is all very interesting. Undoubtedly I have great powers, but I see no chance of using them. All my work is done in collaboration with my Hungarian colleagues, and we have never yet had a single difference of opinion." ${ }^{750}$ This was once again a typical Smith interview: succinct, modest, and going out of his way to praise the efforts of the Hungarian government. After the first barrage of interviews, Smith kept a low profile and spent most of his time with his sister and rested. Only occasionally did he take on public appearances. One was the prestigious annual dinner of the Alumni Association of Boston, in which he took part. ${ }^{751}$

While he was in the United States in November and December, life did not cease in Hungary, although no groundbreaking events took place. The reduction

747 Notes of conversation between the Governor, Mr. Jeremiah Smith, Commissioner General for Hungary, and Mr. Siepmann, November 6, 1925, OV33/40, BoE.

748 Ibid.; Norman to Salter, November 5, 1925, Norman to Niemeyer, December 11, 1925 and Niemeyer to Norman, December 12, 1925, all in OV33/40, BoE.

749 Boston Daily Globe, October 29, 1295.

750 The New York Times, July 11, 1926.

751 Boston Daily Globe, December 10, 1925. 
in the National Bank's interest rate had not affected the ruling customs as far as interest rates went. In Budapest, the average was 12-13\%, while in the provinces, three-month loans tended to charge $20 \%$ per year. In mid-October, control and restriction of foreign exchange was repealed. The most momentous event took place on November 6, 1925, when the National Assembly passed the bill providing for the introduction of the Pengö from January 1, 1927, based on gold. It would be equivalent of 12.500 paper crowns and its ration to the two leading foreign currency would be as follows: $1 \mathrm{f}=27.825$ gold crowns and $1 \$=5.7176$ gold crowns. ${ }^{752}$ Upon Smith's and the League's prodding, the Hungarian government, in a meeting held on November $27^{\text {th }}$, decided that state money could be only held at the National Bank or at the Royal Hungarian Postal Savings Bank. ${ }^{753}$ Although it was not carried out in absolute measures, it was an important step to break with older traditions, and a few months later a further decision now named the National Bank as the sole place where state moneys could be stored. ${ }^{754}$ Faith in the National bank was strong outside Hungary, especially in the most important place, London. As Norman wrote to his apprentice in Budapest, "so long as M. Popovics is President, the interests of the National Bank will I am sure be in safe hands."755

Smith's latest and prolonged absence gave ground to various conjectures. One of the papers went as far as claiming that the financial control might cease before the originally planned date and the American commissioner would not even come back to Hungary. ${ }^{756}$ Although such rumors reflected wishes rather than reality, their timing was not coincidental. In a few days' time, Geneva hosted the winter session and it was possible that very important decisions would be made in connection with Hungary.

This was the only occasion when Smith could not be present at the Assembly meeting and in front of the Financial Committee. Such task fell on his deputy, Royall Tyler, who "enjoyed it after the first emotion was over." ${ }^{\prime 757}$ The Financial Committee congratulated Hungary and Smith, agreed to the release of $\$ 50$ million gold crowns ( $\$ 10$ million) for productive purposes, but called attention to further commercial treaties and centralization of state funds. ${ }^{758}$ The Hungarian sub-Committee also stated that the overall results of the reconstruction program

752 All the information in the paragraph is from Smith's Nineteenth Report, LNJ, $7^{\text {th }}$ Year, No. 3, March 1926, 466-74.

753 November 27, 1925, 10-11R/46. $7^{\text {th }}$ daily item. K 27, Records of Cabinet Council Meetings, HNA.

754 March 12, 1926, 18-19R/46. 11 ${ }^{\text {th }}$ daily item. Ibid.

755 Norman to Siepmann, December 10, 1925, OV33/40, BoE.

756 Pesti Hírlap, December 1, 1925, XLVII/272.

757 Tyler to Mildred Bliss, December 31, 1925, Tyler Papers.

758 LNJ, $7^{\text {th }}$ Year, No. 2, February 1926, 131. 
so far were commendable. Based upon Smith's earlier report, the Committee listed all the achievements but called attention to what in its opinion was still missing: further liberalization of the tariff policy, although it was a question of closer cooperation with neighboring states, and further decrease in taxes, especially in indirect taxes. ${ }^{759}$ Incidentally, the money given to Hungary for productive purposes was a compromise. Despite the fact that the representative of the Little Entente wanted the question of the 50 million gold crowns to be postponed, the Council agreed to grant it, but at the same time it refused the Hungarian request for the release of the remainder of the loan, (132 million gold crowns, \$26.5 million) for capital investments over a period of three years. ${ }^{760}$ The decision was obviously a political one. On the one hand, the Little Entente with French backing did not want to see Hungary prospering beyond a certain limit if they could help it. On the other hand, Hungary was clearly on the way of recovery and the more it could spend on productive purposes, the sooner it would achieve a fully rehabilitated status, which was the primary goal of the whole reconstruction program. In addition, the overall European goal was that as many countries as possible should prosper and cooperate fully. The Council's decision was a classic political compromise that neither side could really challenge.

The Commissioner-General's report for December did not contain any significant news aside from the League Council's decision. He listed the usual pleasing data: the National Bank's metal reserves had been gradually rising overall and were very satisfactory; the past few months showed a slight favorable trade balance; retail prices had been the lowest since the reconstruction law was passed; and deposits in the banks further grew. ${ }^{761}$ Despite the favorable results, Smith warned against increasing expenditure, because the past few months had been the best and they might be misleading in the long run. Still, he concluded with his now trademark optimism that "the possibility of the permanent equilibrium of the Budget can be looked to with confidence." 762 As the year of 1926 began, all concerned were aware that the financial reconstruction of Hungary had been on the right track and unless unexpected disaster struck, the planned conclusion to the work in six months' time would be a reality.

The two months Smith spent home were enough to recharge his batteries. The quiet surroundings of New England, the getaway from the daily strain of

759 Meeting of the Committee of the Council for Hungary, December 7, 1925, Financial Reconstruction of Hungary, Provisional minutes of the $9^{\text {th }}$ Session: December 1925. Doc. No. 48287, Registry Files, R. 301, LNA.

760 Ibid.; LNJ, $7^{\text {th }}$ Year, No. 2, February 1926, 231-32. In addition, Hungary was warned once more to conclude more commercial treaties and further suppress the number of officials. Ibid.

761 Smith's Twentieth Report, LNJ, $7^{\text {th }}$ Year, No. 3, March 1926, 475-83.

762 lbid. 
work, and the positive results so far all made Smith look forward to the next and hopefully closing period. He sailed back to the old continent on January $1^{\text {st }}$ and, after a few days in London and Geneva, he arrived on the Orient Express back in Budapest in mid-January. ${ }^{763}$ The Hungarian newspapers reported the event as a major one. Giving weight to the return of the Commissioner-General, even photographs appeared in some of the papers. ${ }^{764} \mathrm{~A}$ conspicuous feature was his returned vigor. As one paper described, "he returned to Hungary with great joy and wishes with renewed energy to work, in cooperation with the government, on the economic reconstruction of the country. ${ }^{1765}$ Just as an echo to this news, right after his arrival, Smith met with Bethlen and Bud and conferred with them about the past two months and the next period. In a special interview given to a paper the same evening, Smith had good news to tell.

I am happy to state that the foreign circles concerned with Hungary all share the same opinion that today the success of the reconstruction is a fact [...] They see that Hungary has managed to own all the tools that can guarantee the confident progress of the economic improvement [...] Based upon my impressions elsewhere, foreigners look upon the Hungarian economy with the biggest trust. ${ }^{766}$

This was confirmed by the Hungarian legation in Washington. In its January report it emphasized that the favorable opinion in the United States was attributable to Smith's reports that always got place among the news, and the American population heavily relied on them in formulating its opinion about the Hungarian economic and financial situation. ${ }^{767}$ When Smith was asked about the recently uncovered franc forgery, he quickly demonstrated his apolitical nature again and tersely replied, "I do not deal with this question."768

763 Boston Daily Globe, December 31, 1925; Brentano to Kellogg, January 30, 1926, 864.00/669, Roll 7, M. 708, NARA.

764 Magyarország, January 15, 1926, XXXIII/11; Pesti Napló, January 15, 1926, 77/11.

765 Budapesti Hírlap, January 15, 1926, XLVI/11.

766 Pesti Napló, January 15, 1926, 77/11.

767 53/1926 I-5. Washington I/57, K 66, Press and Cultural Department, HNA.

768 Pesti Napló, January 15, 1926, 77/11. On December 14, 1925, a Hungarian officer Aristid Jankovich was arrested in the Netherlands when trying to pay with forged 1,000 French franc note. From the end of January, Bethlen was also compromised, but Horthy, Apponyi, Great Britain, and Italy were backing him. First, some officials in the French foreign political establishment wanted to make use of the scandal and cause a government crisis or change in Hungary, but nothing came of it and during the League session in March, the franc forgery was not dealt with officially. Finally, the alleged perpetrators got their not too heavy sentences in the summer. More about the scandal in detail, see Ignác Romsics, "Franciaország, Bethlen és a frankhamisítás," [France, Bethlen, and the Franc Forgery] Történelmi Szemle 26 (1983): 67-86. 
Back in harness, Smith focused with all his energy on the reconstruction. He was in an easier situation compared to when he had started, because the past year and a half had been ample proof that the goal would be reached comfortably by the planned deadline, June 30, 1926. The Geldinstituteszentrale remained on the agenda. The British axis, Norman and Siepmann, was of the opinion that President of the National Bank Popovics was the key person, who should have put more pressure into restricting the functions of the institution. Norman simply said that the institution "should be suppressed," although he did not question its sometimes useful role in the unusual Hungarian circumstances. ${ }^{769}$ Niemeyer urged Smith that this question be solved as soon as possible, especially in light of the franc forgery scandal. ${ }^{770}$ Smith replied that the government had seemingly made up its mind that all state moneys should be concentrated at the National Bank, but in order to avoid it without aggravating the local opinion any further in this question, the Geldinstituteszentrale should be "bought off." ${ }^{771} \mathrm{He}$ also laid pressure on finance minister Bud in this question. He managed to get a personal guarantee from him that by the end of June 1926, the problem would be settled "beyond any possibility of cavil," even if there were voices against this move. ${ }^{772}$ The Center would be reorganized to its original function, that is, to provide help in exceptionally difficult times. Strangely, the nagging and unsettled question of this institution had been on the agenda basically all through the reconstruction period and never seemed to go away. Once again it was evidence that old traditions died a very slow death in this part of the world.

In January the National Assembly accepted the State budget for the 1925/26 fiscal year. 20 million gold crowns (\$4 million) were temporarily released from the loan for buying silver and other metals necessary for coinage of the new currency. The sum would be repaid as soon as coins had been minted and were ready to be put into circulation. Right after the franc forgery scandal began, speculators started to take advantage of the situation, but the Bank was able to offer unlimited amount of foreign currency and thus saved the stability of the Hungarian currency. $£ 1,000,000$ of the $7 \%$ Land Mortgage Bonds of the Hungarian Land Mortgage Institute (Magyar Földhitel Intézet) was issued in London with success. The bankers paid 86.5 and it was offered at 93 to the public. Although food prices were on a similar or lower level compared to other countries, some manufactured articles were two to ten times as expensive as in Paris, London, or New York. The question of how to spend the surplus and the

769 Lojkó, Meddling in Middle Europe, 125-26.

770 Niemeyer to Smith, January 11, 1926, OV9/439, BoE.

771 Smith to Niemeyer, January 22, 1926, Ibid.

772 Siepmann to Norman, February 3, 1926, OV33/41, BoE; Magyarország, April 9, 1926, XXXIII/79. 
released money by the League for capital investments came to the fore again. The list included twenty-one different items on which the 73 million gold crowns ( $\$ 14.6$ million) were going to be spent. Among the many items such various recipients were named as municipal public hospitals, schools, development of the public road, short-term agricultural loans, tobacco planters, the previously mentioned Geldinstituteszentrale, State Ironworks, Port of Budapest, and Drainage Societies. ${ }^{773}$ Smith later approved a further increase of 55,000 gold crowns $(\$ 11,000)$ for the Komló State coal mines and 2 million gold crowns $(\$ 400,000)$ for the Central Credit Association for Agriculture. ${ }^{774}$ But Smith did not consent to the inclusion of establishing branches of the State vine cellars in Vienna, Warsaw, and Germany, simply because he did not think that it would be the kind of capital investment the League of Nations had in mind. ${ }^{775}$ Smith thus was not giving a blank check for Hungary so that they could spend the surplus on whatever they thought. If they wanted to include something in the investment program that did not fit Smith's ideas, he would stubbornly refuse it.

\subsection{The Closing Accords of the Great Work}

The next few months brought a calm prelude to the grand finale. No major events took place in February and March, and Smith had only good news to tell once more. In 1925, unfavorable trade balance was only minus $5.4 \%$ but the total volume of trade had been growing. On February $21^{\text {st }}$, the commercial treaty with France entered into force, but most importantly, after a year of negotiation agreement had been reached with Austria on commercial convention. The convention signed on February $27^{\text {th }}$ was the highlight of the discussed period and the first concluded with a really important country as far as trade went. Obviously, this was a very important agreement since Austria was Hungary's most important trade partner and had taken so far one-third of Hungary's total export. The agreement was first and foremost lucrative to the flour and wine industries. With the new regulations, these products could enter the Austrian market with an approximately $50 \%$ reduction in duties. ${ }^{776}$ What Smith could add

773 All the information in the paragraph is from Smith's Twenty-first Report, LN], $7^{\text {th }}$ Year, No. 5, May 1926, 678-88. On the Land Mortgage Bonds, see Péteri, Revolutionary Twenties, 191-97.

774 Smith to Bud, February 22, 1926, and April 1, 1926, B.V. (3) Budget Surplus Account, 1924-25, C. 109, Financial Reconstruction of Hungary, LNA.

775 Smith to Bud, April 19, 1926, C.III (7) Correspondence - Hungarian Ministers, 1926, C. 111, Financial Reconstruction of Hungary, LNA.

776 All the information in the paragraph is from Smith's Twenty-second Report, LNJ, $7^{\text {th }}$ Year, No. 5, May 1926, 689-97. 
in his March report was that thanks to improved conditions and better method of collection, there had been a gradual and steady increase in the direct taxes, which almost doubled, while in the case of the turnover taxes a similar decrease had taken place. ${ }^{777}$ This was judged by Smith to be a step in the right and healthy direction. He was also satisfied in reporting that both retail prices and wholesale prices had reached the lowest point since the start of the reconstruction period, though the latter was still $123 \%$ compared to the prewar level. ${ }^{778}$ In the true fashion of "the good news is if there is no news," the financial reconstruction of Hungary was advancing at a nice pace without any major obstacles. The work done so far only portended the successful conclusion in a short time.

By April the state debt to the National Bank had been reduced by a large margin and there was a new agreement between the two sides for further reduction of such debt. It was a welcomed further step in the direction of currency reform and reaching Article 83 of the Statutes of the Bank, which declared that the government debt must be reduced to 30 million gold crowns ( $\$ 6$ million). The concentration of government balances at the National Bank had been carried out for the most part in the past month. A beginning was the transfer of Postsparkassa monies from the Geldinstitutszentrale to the National Bank. Those government balances remaining at the Geldinstitutszentrale would be concentrated at the National Bank by the end of June 1926, as had been promised earlier. All this indicated that the path planned and thought best was and would be traveled by the Hungarian government. The news that a commercial treaty with Spain entered into force on April $18^{\text {th }}$ also bore some significance. Both retail prices and wholesale prices had reached another record low point and deposits in the banks kept growing. ${ }^{779}$

The most momentous episode was not mentioned in the monthly report. It was Smith's letter to the League of Nations in which he forwarded Bethlen's request that he expected "to raise the question of the termination of the control of Hungarian finances, under the Geneva Protocol No. 2, at the June Meeting of the Council." 780 In the December meeting of the Hungarian Committee, the representative of the Little Entente was against the release of 50 million gold crowns (\$10 million) from the loan because, as they stated, they had not had enough time to study the question. As the letter disclosed, the reason why the Hungarian Prime Minister was already thinking about this sensitive issue was "that all interested parties may have time to prepare themselves for the

777 Smith's Twenty-third Report, LNJ, $7^{\text {th }}$ Year, No. 6, June 1926, 778-86.

778 lbid.

779 All the information in the paragraph is from Smith's Twenty-fourth Report, LNJ, $7^{\text {th }}$ Year, No. 6, June 1926, 787-96.

780 Smith to the Secretary General, April 24, 1926, Financial Reconstruction of Hungary, Cessation of the control of Hungarian finances. Doc. No. 51126, Registry Files, R. 301, LNA 
discussion of this matter." ${ }^{181}$ Bethlen's move was well-founded. He knew that he could not expect anything favorable from the Little Entente. The mutual dislike between Hungary and these countries, burdened with the problem of the franc forgery, which the Little Entente wished to use as a possible card against Hungary, made Bethlen play it safe. And since the question was that of the termination of direct control, he was well aware that he had to act ahead of time, so that the Little Entente would have fewer possibilities to cause trouble. Lukewarm May was only a prelude for the climax in June, that is, the anticipated termination of financial control.

In early June during the summer Assembly of the League of Nations, the main point was the termination of the control of finances both in Austria and Hungary. The franc forgery was a serious issue, because France and the Czechs might have wanted to use it as a weapon not to let the control be lifted. This, in turn, could have meant Bethlen's fall, which Britain did not want to see. As a Foreign Office minute put it, "If there is a danger of their [the French] doing this it may be advisable for us to make representations to the French Govt. before the meeting of the Council [in June] so as to convince them of the error of their ways." ${ }^{\text {"782 }}$ In fact, it was no secret that the French were planning to ask for postponement of the termination of control exactly due to the forgery scandal. ${ }^{783}$ The British were determined not to let the French have their way and put off the decision about lifting the control in Hungary till September. ${ }^{784}$ The British were angry and with good reason. The Protocol said that control should cease if the financial stability of Hungary was achieved, but for such a declaration unanimous decision was needed. If the French or the Little Entente wanted to play hardball, there was a danger that such a decision might not be reached.

The representatives of France and the Little Entente on the Financial Committee acted as expected. Vilem Pospisil, the Czechoslovak representative eon the Financial Committee, thought the decision about decontrol should be postponed, but Strakosch, Niemeyer, Wallenberg, and ter Meulen defended the end of control by June $30^{\text {th }}$, since, the main aim, that is, financial stability had been achieved. Even the French chairman, Dubois thought that since the post of the Commissioner-General was coming to an end in Austria, then in Hungary,

\footnotetext{
$781 \mathrm{lbid}$.
}

782 Minute by unknown FO official, May 21, 1926, F0371 11369 C5795/443/21. See also Goode to Niemeyer about the position of Bethlen, Goode to Niemeyer, May 11, 1926, Ibid. 783 Ross to Niemeyer, June 3, 1926, C6375/443/21, 11369, F0371, TNA. Still, according to Siepmann, who based his information on Charron, the French man on Smith's team the French minister in Budapest wrote to Paris that he favored the complete abolition of control at the end of June. Siepmann to Norman, May 31, 1926, OV33/42, BoE.

784 Crewe to Chamberlain, June 2, 1926, C6443/433/21 and Niemeyer to Lampson, June 4, 1926, C6392/443/21, 11370, F0371, TNA. 
which seemed to be in a stronger position financially, it should also come to an end. Maybe more importantly, it would be a loss of prestige for the League if decontrol was deferred, in addition to which, Smith had himself asked to be relieved from his post. ${ }^{785}$ There was unanimous agreement that the post of the bank adviser should cease, but as for the reliquat, the decision was, after a close vote, that at the moment nothing should be said about it. ${ }^{786}$ Smith thought the Financial Committee should show signs of resolve and not allow politics to dictate their decision. ${ }^{787}$ Finally, in its report to the Council, the Committee stated that in its examination of the financial position of Hungary it "considered the financial and economic data furnished to it [and] it does not consider that such circumstances as the franc forgeries (entirely deplorable as they were) have affected the financial position of the country." ${ }^{\text {"788 }}$ In Salter's opinion, "the knowledge of the Council's ultimate right was effective in securing unanimity in the Committee. ${ }^{1789} \mathrm{~A}$ few days later the Financial Committee officially agreed to the termination of the office of the Commissioner-General. ${ }^{790}$ According to British memorandums, it was wholly attributable to Chamberlain's efforts, and Bethlen's position was more secure than ever. ${ }^{791}$ In any event, the main objective of lifting direct control was achieved. The next day Smith thanked the Hungarian government and people for their continual cooperation, for the Financial Committee for its work, and for the Council for entrusting him with the job and giving support all throughout the reconstruction period. ${ }^{792}$ It is important to note that the termination of the post of the Commissioner-General did not mean the end of control of Hungarian finances. Control over the revenues from the assets assigned for the service of the loan and over the balance of the loan remained in place after June $30^{\text {th }}$. The key person to act as the bridge between the League of Nations, the Trustees, and the Hungarian government would be Royall Tyler, the

785 Actually, Siepmann believed that Smith's sickness may have been a major factor why control was brought to an end by the end of June. He characterized Smith as "tired and ill. He looks to me at the moment like a sick man." Siepmann to Norman, May 31, 1926, OV33/42, BoE.

786 Financial Committee, Twenty-second Session, Minutes of the Fourth Meeting, June 4, 1926, OV9/340, BoE.

787 Siepmann to Norman, May 31, 1926, OV33/42, BoE.

788 Report of the Financial Committee to the Council, June 6, 1926, Financial Reconstruction of Hungary, Deliberations at the $40^{\text {th }}$ Session of the Council, June 1926. Doc. No. 52083, Registry Files, R. 302, LNA.

789 Salter, The United States of Europe, 68.

790 Work of the Financial Committee during Its Twenty-second Session, June 3-9, 1926, C. 359. M. 127. 1926. II, LNA.

791 Selby's Memorandum, June 10, 1926, C6695/443/21 and Chamberlain's memo in Chamberlain to Tyrrell, June 9, 1926, C7619/443/21, 11370, FO371, TNA; Barclay's minute, June 16, 1926, C7059, 11368, FO 371, TNA.

792 LNJ, 7th Year, No. 7, July 1926, 876-77. 
deputy of Smith, also an American, who enjoyed the backing of both the League and Bethlen. ${ }^{793}$

Smith was highly praised by all sides. One League representative was of the opinion that "Mr. Smith's personality, the breadth of his views, his tact, his indefatigable energy and, his rare kindness, had been among the principal factors in the success of this difficult work." 794 Bethlen, who besides praising the Hungarian people, the League of Nations, and the Financial Committee said that "Hungary owed a particularly large debt of gratitude to the Commissioner-General and his collaborators [who showed] wide understanding and sympathy towards

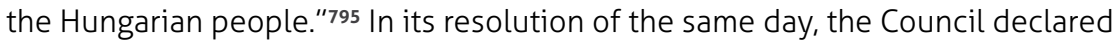
that Smith's functions would end on June 30, 1926, since the financial stability of Hungary was assured. It also expressed its "deep appreciation of his work," and concluded that "the rapid completion of his task at the date contemplated in the original programme is due in no small measure to the personal qualities he has shown-to his disinterested devotion and his sound judgment."796 Eric Drummond thanked Smith in a personal letter and emphasized the personal relations as a key to the success achieved. ${ }^{797}$ Smith obviously felt the same, since it was his worldview to move issues onto the personal level where it would be much easier to solve them diffused from political content. However cordial his relationships were to Geneva, Smith used to call the League Secretariat a "Madhouse."

Smith was also in high esteem in Hungary. Apponyi, the grand old man of the country, lavishly commended Smith's work and spoke of the puritan gentleman thinking that characterized the American commissioner. ${ }^{799}$ As a reply to this, another Member of Parliament said that "Smith, during his work, cared for the interests of the country to such an extent that in case he should leave us, we ought to line up at his departure to express our appreciation his work is worth." ${ }^{1800}$ In the National Assembly, Prime Minister Bethlen spoke highly of Smith's work

793 Ter Meulen to Salter and Strakosch to Salter, June 18, 1926, and Bethlen to Salter July 5, 1926, Financial Reconstruction of Hungary, Services and expenses of Mr. Tyler, a representative of the Trustees in Budapest. Doc. No. 52197, Registry Files, R. 302, LNA.

794 Extract from the Minutes of the Council, June 10, 1926, Financial Reconstruction of Hungary, Deliberations at the $40^{\text {th }}$ Session of the Council, June 1926. Doc. No. 52083, Registry Files, R. 302, LNA.

795 lbid.

796 lbid.

797 Drummond to Smith, June 15th, 1926, Financial Reconstruction of Hungary, Appointment of a Commissioner General by the League. Doc. No. 33315, Registry Files, R. 298, LNA.

798 Tyler to Mildred Bliss, May 2, 1933, Box 3, Tyler Papers.

799 Budapesti Hírlap, May 22, 1926, XLVI/114.

800 lbid. 
in Hungary. This part of his speech was underscored with the outlook for further American loans. Bethlen thanked Smith for the fact that he had

worked in the reconstruction of the country upon objective points of view, with love and sympathy for this fallen Hungarian nation, and helped to save us from the morass, from the difficulties, and strenuous past from which only by the League of Nations and his help have we been able to get out. I thank him, the American citizen, who had proven that if an American citizen undertakes a task, he will carry out true to the tradition of that great nation; he has done this in the post he represented in Hungary. ${ }^{801}$

Indeed, Smith's consequent apolitical manner all throughout his tenure as Commissioner-General appealed to basically everyone. Naturally, the ruling general feeling in the country concerning the close departure of the Commissioner-General was that of relief. After all, the country would regain its financial independence, which was no small issue. In this relation, few people minded Smith's leaving. As for Bethlen, the main point about lifting the control was, for both domestic and foreign policy reasons, that "the end is in sight." 802 Finance Minister Bud may actually have been the only one not happy to see Smith leave. He was afraid about the pressure for money that now he would be experiencing from the various departments. ${ }^{803}$ Another exception was the Public Servants National Union, which was specifically sad that Smith's time was winding up, because they had so much hope in the American as far as the question of pensions were concerned. ${ }^{804}$

Hungarians were grateful for their American Commissioner-General with good reason. The financial reconstruction of Hungary was not only successfully concluded but exceeded the most optimistic expectations. In his final report covering both May and June, which was completed afterward, as was usual in the case of each month, Smith did not deal too much with the specific numbers for the months, but instead put the emphasis on overall significant figures and conclusions. For one, total receipts from the pledged revenues in the 1925/26 fiscal year was 258 million gold crowns (\$51.5 million), eight times the annual service charge, which was 33 million gold crowns ( $\$ 6.5$ million). In light of this it was no big surprise that budget surplus for the same fiscal year was 62 million gold crowns (\$12.5 million), a large sum indeed. From the almost 253 million loan,

801 National Assembly Diary, 1922-27, 25:42.

802 Siepmann to Norman, May 31, 1926, OV33/42, BoE.

803 lbid.

804 Public Servants National Union to Smith, June 20, 1926, K. I. - K. A. N. Sz., C. 113 , Financial Reconstruction of Hungary, LNA. 
only 70 million had to be spent on budget deficits and back debts to June 30, 1924. 100 million gold crowns (\$20 million) had been authorized by the League Council for capital investments, and there was 81 million (\$16.2 million) left as available from the original amount. Not only had the originally required reforms been carried out, but in addition those suggested by the Financial Committee had also been executed. These latter ones were state money centralization at the National Bank, laws requiring annual publication of all expenditures and receipts of the Government not included in the ordinary budget, and monthly statements of estimated expenditures and receipts. On the whole, during Smith's tenure there had been a continual increase in banks deposits and both retail and wholesale prices had seriously decreased. Smith, as always, praised the assistance and support he had been given all along. As he phrased it, "without the co-operation of both the Government and the people, it would have been impossible to make any satisfactory progress with the reconstruction plan, and this has been completely given at every stage of the work." ${ }^{805}$

Smith proudly declared that the League of Nations had met the challenge and performed its duty and the responsibility expected of the international organization:

The League has now done all that it undertook to do-i. e., to create a sound budgetary and financial position, which is necessary to establish a firm foundation for the future upon which the complete economic recovery of Hungary can take place. Economic conditions have slowly and steadily improved since the plan became effective, and if the present position is maintained by Hungary itself, the economic conditions should continue to improve until they reach at least the normal pre-war conditions..$^{806}$

This last statement is important, because it clearly shows that regardless of the euphoria felt by the successful conclusion of the reconstruction program, the comparison with pre-war Hungary in economic terms still lagged behind. This was not the fault of the program. Rather, this proved how low Hungary had stood at the end of the war and the social and political disturbances shortly after the war not only from a financial but also, and mainly, from an economic point of view.

Smith also had a slight warning to give. Despite the rosy numbers at the moment, he warned against imprudent fiscal policy in the future. One of the problems had been the high taxation, which was new to Hungarians and made

805 All the information in the paragraph is from Smith's Twenty-fifth Report, League of Nations, Financial Reconstruction of Hungary, 164-87.

806 Ibid., 169. 
a lot of sacrifice on the population. Smith wrote that if there appeared an unbalanced budget once more, the only recourse for the government would be to raise taxes, obviously a risky choice from every aspect. The solution was conservative fiscal policy and to avoid raising expenditures. He listed the longterm loans issued during the time of the reconstruction. These were issued on $7.5 \%$ and meant about 51 million gold crowns ( $\$ 10.2$ million) annuity. In addition to the long-term loans, there was a considerable amount of shortterm foreign credits outstanding. The total amount of these was very difficult to calculate since they showed significant fluctuation. But from the information available, it was not believed that it was excessive "or likely to throw an undue strain upon the financial situation of Hungary." ${ }^{807}$ In hindsight, it can be easily stated that the ever-optimistic American was wrong in predicting the future in his final report, but the fault did not lie with him, but rather with the unstrained borrowing of the Hungarian government in the next few years. But he also said that something would go wrong. Siepmann was already starting to be afraid of what he termed "the free-lance borrowing" practiced by Hungary. ${ }^{808}$ He had not shared the optimism of Smith almost all throughout the reconstruction period, and toward the end he drew a different conclusion. His sharp observation to Norman deserves to be quoted: "I hope, and on the whole I believe, that the League will have the wisdom to get out of this undertaking while it still looks something like a success." ${ }^{809}$ Indeed, in five years time, the debt of Hungary reached a very high numbers and there was no chance to repay them.

With Smith's departure on July $1^{\text {st }}$, the financial control did not cease altogether, although it became much looser. As was mentioned, Smith's deputy, Royall Tyler, who did a very useful job, was entrusted with the nominal control of the Hungarian finances. Tyler enjoyed sympathy from all sides and had no trouble keeping up the cordial relation that Smith had established. His reports, drawn up in a similar fashion to Smith's, and opinion were important. It was his agreement with the government's plan that made the League authorize a further 50 million gold crowns ( $\$ 10$ million) from the loan in March $1927 .{ }^{810}$ It was again his consent that needed a few months later for the remaining sum of 33.9 million gold crowns ( $\$ 6.8$ million) to be given to the Hungarian government. ${ }^{811}$ Finally, Tyler's mission

807 lbid.

808 Siepmann to Norman, May 19, 1925, OV33/39, BoE.

809 Siepmann to Norman, May 31, 1926, OV33/42, BoE, also quoted in Péteri, Revolutionary Twenties, 202.

810 Work of the Financial Committee during Its Twenty-Sixth Session, C. 152. M. 44. 1927. II, LNA. The 1927/28 fiscal year was also a success. Both revenues and expenditure grew, although budgetary surplus was 97 million pengôs compared to 121.5 in the preceding fiscal year. Eugene Havas, Hungary's Finance and Trade 1928 (London: London General Press, 1929), 7.

811 LNJ, 9th Year, No. 2, February 1928, 127. 
came to an end in June 1929 and less than one year later the function of the Committee of Control was terminated as well. ${ }^{812}$ With these final steps Hungary absolutely regained its financial freedom. Unfortunately, the government did not heed the good advice and Hungary used more and more loans. While in 1926 it was a reasonable $\$ 29.51$ million, it almost doubled in the next few years, and tripled in 1931, reaching $\$ 87.57$ million. ${ }^{813}$ Another interesting feature was the ration between British and American investments in Hungary. While at the start of the reconstruction, British investments were totaling at $\$ 38,487$ million, more than four times larger than the American $\$ 9$ million, in the next few years the trend reversed and in 1928 the American investments were almost double of the British ones. ${ }^{814}$ To give a testimony to the leading character of these two countries in terms of money coming to Hungary, of all the investments between 1924 and 1930, the United States had 44.5\%, while Great Britain had 40\%, of the total investments, thus these two countries were responsible for $84.5 \%$ of the total. ${ }^{815}$

The financial reconstruction of Hungary, parallel to the Austrian one, which came to an end on the same date, was a very successful achievement of the League of Nations. Austerity measures seemed to work. The organization, whose prestige was on the line, emerged as a body that was capable of organizing international cooperation on a large scale. Its reconstruction programs paved the way for the German reconstruction known as the Dawes Plan and further European reconstruction programs in Eastern and Southern Europe.

\subsection{Balance Sheet}

After all this it is worth concluding the balance sheet of the reconstruction period in Hungary. The international loan was used for the original plan, that is, to create a stable currency and achieve budget equilibrium instead of deficit, only in the first half year of the program. This, in turn, begs the question: why was so big a reconstruction loan needed in the first place? One reason is that League of Nations estimates for the period of the reconstruction were too conservative, or just too cautious, and they predicted substantially less money from the assigned revenues. But perhaps a more important reason lies in the thought behind the reconstruction of all Europe, which did not only

812 Tyler later returned to Hungary in 1932 as financial adviser to the government and remained in that capacity until 1938 . He also mastered the Hungarian language during his protracted stay.

813 Péteri, Global Monetary Regime, 138.

814 Péteri, Revolutionary Twenties, 180.

815 lbid. 
mean economic-financial rehabilitation, but political stability as well. It was important for the Western powers that Hungary should have and be able to maintain a strong and stable government, even if the idea of democracy was seriously curbed. This was achieved and Hungary performed well. During the reconstruction period, state revenues of all kinds continuously rose, and the tax reductions introduced in 1925 did not alter this trend. The budget kept producing surplus. Even after the program was over, in the 1927/28 financial year the state budget could boast of a 97 million surplus, which was from all angles a great success. ${ }^{816}$ On the other hand, Hungary started to find itself more and more in debt, which course speeded up after 1926, and by the summer of 1928 it reached 1778.9 million pengős (\$311 million), a staggering amount compared to the size of the country. ${ }^{817}$

The reconstruction program, without a doubt, achieved the goals it set out to reach at the commencement. The Hungarian currency became very stable and inflation disappeared at the very beginning of the program. Budget deficit was a thing of the past from 1925, and even considerable surplus was realized. This was largely achieved by reducing expenditure and raising revenues by a large margin. A great asset in this was the new tax system, in the wake of which the population had to bear a high per capita taxation relative to Hungary. State moneys were concentrated at the National Bank, which was another important element of healthy fiscal and monetary policy. The Bank managed to reduce the interest rate, and from the $12.5 \%$ at the start it shrank all the way to $6 \%$ in August 1926. Parallel with all this, the reduction in the numbers of state employees was also carried out. The Hungarian government reached the promised number in the first year. The number of state officials decreased from 198,000 to 160,000 , which was somewhat more than promised. The salaries of these officials rose too, although this hardly alleviated their pecuniary hardship. The expenses on personnel meant a huge burden on the state. $60 \%$ of the whole budget was spent on personnel alone, salaries and pensions, and by the end of the reconstruction period this number showed only a minimal decrease of $5 \%$. Although this was still too high, it was a step in the right direction. The Hungarian state managed to conclude a series of trade agreements based on the principle of the most favored nation, and by the end of 1926, most of the neighboring countries were included in this circle.

816 The budget surplus showed the following picture (in million pengős): 1924-25: 131,7; 1925-26: 98,1; 1926-27: 143,6; 1927-28: 97; 1928-29: 2,5; 1929-30: 2,2. Magos, Az angol és amerikai monopoltöke szerepe a Horthy-fasizmus megszilárdításában (Budapest: Múvelt Nép Könyvkiadó, 1953), 67.

817 "Dealing with Hungary's Finances," VII/5, Hungary's Financial and Economic Situation, K 284, Szabóky Papers, HNA. 
With all the favorable results, the negative effects of the program also surfaced. The steps leading to the increased revenues, such as the higher taxes, ${ }^{818}$ higher customs duties, or freeing the market, caused a general rise in prices and a lower standard of living for the population in general. The above mentioned rise in the salary of the officials still lagged far behind the desired level and could hardly ensure that these people would make ends meet, and compared to prewar salary levels, they represented only $50 \%$. The number of bankruptcies and insolvencies together with the cases of suicides also showed an unfavorable picture.

Naturally, the political opposition in Hungary was not very enthusiastic with the results. Many of them found fault with the fact that the government succeeded in achieving the outcome only by squeezing money from the citizens. Basically it was the clash of ideas in favor of austerity and giving up some freedom versus more political independence at the possible price of facing protracted recession. The opposition also attacked Bethlen because the remainder of the loan, about 82 million gold crowns ( $\$ 16.4$ million), was not freed at the end of the reconstruction program, and that Smith's departure only meant the on-the-ground supervision, but control was not wholly demolished. Behind this the opposition suspected was the issue of the franc forgery. ${ }^{819}$ Bethlen in his answer tried to refute the charges in a curt way, then said the following, which in hindsight was very important. "We need to take great care, despite the hard conditions, not to make this country deep in debt. And believe me, my fellow representative, it is hardly sufficient to create investment plans for the next year, or for the next two to three years. We will have to make such plans for decades in case we want this country to recover to some degree, and this will not be possible without further credits and loans from abroad." ${ }^{820}$ With this the prime minister basically projected the course Hungary should not have followed, but what in fact the country did pursue in the next few years. By 1930, Hungary found itself in a devastating amount of debt, and by that time the favorable results of the reconstruction period were also long gone.

818 The tax burdens rose in a substantial way compared to the prewar years, although various sources give different data. According to one, the per capita tax rose from 59 pengős in 1913 to 91 pengős in 1925-27, while another source gave 140 pengős for 1927. A third work on the subject concluded that the net per capita burden in Hungary was 128 gold crowns, which, together with Great Britain, meant the biggest proportion between taxing and GDP with 22\%. Zsuzsa Demény, Századok statisztikája. Statisztikai érdekességek a magyar történelemböl [Statistics of Centuries. Interesting Statistics of Hungarian History] (Központi Statisztikai Hivatal, Budapest, 2001), 170; "Hungary's Economic Conditions," Financial Reconstruction of Hungary, C. 118, R. III. Reconstruction - Economic and Financial Situation, LNA; and Csizik Béla, "Államháztartás és közteher", [State Finances and Public Taxes] Közgazdasági Szemle 75 ( January 1930) 584-85.

819 National Assembly Diary, 1922-1927, 45:43-91.

820 lbid., 99. 
Mention must be made about the reparations as well. Bethlen and his advisors for a long time hoped that they would somehow manage to avoid having to pay this money. Although in this they were frustrated, the finally declared amount of 200 million gold crowns ( $\$ 40$ million) and the twenty-year duration did not mean unbearable burden on the state. To get a much clearer picture as to what this reparation meant, a point of comparison can be provided with the reparations Hungary had to pay after World War II.

Similarly to what happened after World War I, Hungary in 1945 was yet again among the defeated countries. The Paris Peace Treaty in 1947 punished Hungary for this fact. The country had to pay reparations anew, the amount of which this time was $\$ 300$ million. This was already a somewhat reduced figure thanks to the efforts of the United States to lessen the original Soviet plan of $\$ 400$ million. The $\$ 300$ million was due to three countries: the Soviet Union (\$200 million), Yugoslavia (\$70 million), and Czechoslovakia (\$30 million). The payment of this amount had to be done in eight years mainly in goods since Hungary had basically no financial resource. The figure, however, is misleading. This amount in 1947 was worth $\$ 242$ million compared to a U.S. dollar in 1924. Only this factor alone means that after World War II Hungary was forced to pay six times as much reparation as in the 1920s. Obviously further variants complicate the picture. One such element was the conduct of Soviet occupation in Hungary, which practically robbed the country blind in the span of a few years' time, and Hungary paid to the Soviet Union about five times the original $\$ 200$ million.

Hungary paid only 30 million gold crowns (\$6 million) of the set reparations of 200 million gold crowns ( $\$ 40$ million) in the second half of the 1920s. Then, in light of the failed policies in Europe and the Great Depression, the Western powers decided to cancel such payments. After World War II, however, the picture was dramatically different. This time Hungary was made to pay many times more than the required amount of $\$ 300$ million. The multiplier between the two figures that Hungary paid is about 180 , that is, Hungary lost 180 times as much money, or material translated into money, in the period between 1945 and 1953 than between 1927 and 1931. If one also takes into consideration the loss of population and the difference between the productive capacity of Hungary in 1927 and 1945, when the reparations payments started, respectively, the 200-million gold crown reparations in 1927 can be said to have been lenient. 